\title{
DOCUMENTACIÓN PRELATINA EN GALLAECIA
}

\author{
Juan J. Moralejo
}

Universidade de Santiago de Compostela

O primeiro que cómpre facer é agradecer vivamente aos organizadores deste simposio Lingua e Territorio a súa invitación para que lles faga unha presentación sumaria dos datos e problemas principais da documentación lingüística prelatina en Gallaecia, área inseparable do conxunto da área indoeuropea ou indoeuropeizada da Península Ibérica, a península que é Hispania nas fontes latinas. Deixo dito que a cantidade de material documental e de bibliografía obrígame a facer unha antoloxía do moito que habería que presentar e discutir. Fica claro, pois, que non vou instruír o sumario cabal da nosa documentación prelatina e, consecuentemente, non haberá sentenza suficiente e definitiva ${ }^{1}$.

$\mathrm{E}$ antes de entrarmos en materia tamén haberá que avisar de que imos falar nos celtas e, se alguén sente que andamos curtos ou fríos, haberá que lle pedir que non teña desacougo ningún, pois imos falar nos datos lingüísticos e non entramos noutras ordes da cultura material e espiritual que non son de correspondencia biunívoca coa lingua e, polo tanto, o que afirmemos ou neguemos nós agora na lingua non supón afirmar nin negar nada nesas outras ordes culturais, de real ou presunta supervivencia ata hoxe e de maior sensibilidade para afeccións e desapegos, filias e fobias.

Para acougo do posible desacougo quero engadir que a veterana polisemia de celta, céltico (Renfrew 1987: 214) coróase felizmente por Cunliffe (1997: 267) con que «perhaps the only real definition of a

1 Este traballo forma parte do proxecto de investigación Hidronimia prerromana de Gallaecia, subvencionado pola Xunta de Galicia (PGIDT99PXI20402A) e que fago coa colaboración da Prof ${ }^{a}$ Dr $^{\mathrm{a}}$ María José García Blanco.

R. Álvarez, F. Dubert, X. Sousa (eds.): Lingua e Territorio Santiago de Compostela: ILG/CCG, 2006, 191-234 ISBN 84-96530-20-5 
Celt, now as in the past, is that a Celt is a person who believes him or herself to be Celtic».

\section{DOCUMENTACIÓN LINGÜÍSTICA PRELATINA}

Para perfilar o meu tema tiven en conta que nin o material galaico prelatino nin a miña experiencia nel me permiten presentarlles unha acta de prenacemento da que vai ser a lingua galega, caracterizada por feitos tales como a queda de - $l$ - e - $n$-intervocálicos, as solucións dos grupos $c l, c t, f l, p l \ldots$, a gheada... e outros riscos fono- e morfolóxicos que non están na documentación galaica, prelatina ou xa latina, porque ou son posteriores a ela ou non os deixan agromar o nivel e mais a norma desa documentación. Hai outros feitos que si agroman, poño por caso a sonorización de oclusivas xordas e a queda das sonoras en posición intervocálica, pero son feitos xa ben coñecidos, están presentes nos manuais e non teño eu novidade substancial que lles presentar a vostedes; nalgún caso -por exemplo, o betacismo- perderiámonos en cousa miúda de máis e que non presenta, seica, unha liña coherente nin no prelatino nin cara á súa continuación latina e románica.

Deixando de lado o enguedello das citas e das referencias de obra e autor, voume limitar a unha presentación moi elemental, pero tamén moi persoal, de datos ben coñecidos e das liñas básicas do debate verbo da Hispania indoeuropea. Elemental, porque sei que algúns de vostedes non teñen familiaridade coa materia e terei que a presentar desde cero. Persoal, porque teño a ousadía de supor que os que si teñen familiaridade tamén poden ter unha certa necesidade de reciclaxe na liña que lles vou presentar.

\subsection{Documentación directa en Lusitania}

A documentación lingüística prelatina directa na Gallaecia é simplemente cero, estamos no baleiro absoluto -¿remediable algún día? ¡canté!- da área noroccidental delimitada polos ríos Pisuerga e Douro. A documentación directa limítase á Lusitania, con catro ou cinco epígrafes breves e dos que podemos facer uso para a nosa área galaica 
baixo a presunción de unidade lingüística galaico-lusitana. Un destes textos, MLH IV L.1, con moitas dificultades e inseguridades na súa interpretación, procede de Arroyo de la Luz (Cáceres) e é coñecido soamente por unha copia do século XVIII²; outro, tamén de Arroyo de la Luz, é de descubrimento e estudo recentes e non trae moita ou fácil novidade (Villar/Pedrero 2001: 235-274). Os máis aproveitables para unha presentación da lingua lusitana son estes dous epígrafes rupestres:

MLH IV L.2 (Lamas de Moledo, Viseu) RVFINVS ET / TIRO SCRIP/SERVNT / VEAMINICORI / DOENTI / ANGOM / LAMATICOM / CROVCEAI MACA / REAICOI PETRANIOI R / ADOM PORGOM IOVEAI / CAEILOBRIGOI

MLH IV L.3 (Cabeço das Fráguas, Sabugal, Guarda) OIL AM TREBOPALA / INDI PORCOM LAEBO / COMMAIAM ICCONA LOIM/ INNA OILAM VSSEAM / TREBARVNE INDI TAVROM / IFADEM / REVE TRE

Véxase que, ademais dos facilmente recoñecibles PORCOM e TAVROM, temos un LAMATICOM para relacionar co común lama, lameiro... e mais cos abundantes topónimos Lama(s) -jde Lamas procede o texto!- e derivados; e temos tamén un teónimo CROVCEAI que a opinión común relaciona co actual croio.

\subsection{Documentación indirecta en Gallaecia}

O que si temos para Gallaecia e para toda a Hispania romanizada e latinizada é documentación directa latina, abundancia de epígrafes en que atopamos feitos puntuais ou sistemáticos de interese para o coñecemento das linguas que de prelatinas pasaron a colatinas, pero nun proceso de bilingüismo diglósico que axiña fixo exclusiva a lingua latina, e das prelatinas non deixou outra pegada máis que o feixe de feitos fónicos, gramaticais e, sobre todo, léxicos que chamamos substrato.

Téñase en conta que, ao contrario do que ocorre noutras áreas europeas, asiáticas e africanas, en Occidente romanización e latinización son conceptos biunívocos e o latín tamén vai ser protagonista

Quizais o texto copiado como único pódese descompor en dous textos e de aí a vacilación entre catro ou cinco para o total de textos lusitanos. 
da cristianización e da súa liturxia e predicación dos textos sagrados. O plurilingüismo oficial que temos, poño por caso, nos arquivos hititas, nas tumbas dos reis aqueménidas, na pedra de Rosetta... ou as traducións gótica, armenia, eslava... da Biblia contrastan fortemente co panorama occidental. Un bilingüe de latín e ibérico, ou celtibérico, ou lusitano... é un imposible, seica, e os comezos latinos dos textos lusitanos (véxase o de Lamas) non son dese bilingüismo que botamos en falta, senón a testemuña de que os lusitanos foran alfabetizados en e para a lingua latina e o de escribir a lusitana non pasa de ensaio ocasional en ámbitos culturais nos que hai persistencia clara das pautas indíxenas fronte ás romanas.

\subsubsection{Epígrafes en latín oficial}

Dentro da documentación latina directa temos moitos epígrafes con niveis, normas e contidos que imos chamar oficiais; son inscricións nas que soamente un erro ocasional, infrecuente, do redactor ou do lapicida pode revelar o que se arreda do latín oficial e correcto. Por exemplo, IRPL 55, a tessera hospitalis do Courel, é latín impecable e o seu interese lingüístico prelatino limítase aos antropónimos dos indíxenas intervenientes no pacto (por exemplo, TILLEGVUS AMBATI F. SVSARRUS $\supset$ AIOBAIGLAECO).

\subsubsection{Epígrafes en latín indíxena}

Ese interese é o que teñen as inscricións que non son romanas, senón indíxenas polos seus temas e contidos do ámbito privado. En especial, dedicacións e exvotos a divindades e lápidas sepulcrais, sempre con textos breves, de sintaxe mínima e formular, frecuentemente reducida ao ben coñecido repertorio de abreviaturas $(D<i s>$ $M<$ anibus $>S<$ acrum $>\ldots H<i c>S<i t u s>E<s t>\ldots V<$ otum $>L<i$ bens $>$ $S<$ olvit $>$...), e sen espazo para léxico común amplo e diversificado. Son inscricións con pautas latinas de lingua e redacción, pero teñen para nós un alto valor documental en que primeiro son depósito da onomástica indíxena en todos os campos -teónimos e epítetos teonímicos, etnónimos, antropónimos, tamén topónimos e hidrónimos-, e 
segundo, nesa onomástica reteñen elementos morfolóxicos indíxenas, non latinos, ademais de documentar tendencias fónicas dos falantes indíxenas suxeitos á latinización. O material complétase cos autores gregos e latinos que trataron cousas de Iberia/Hispania e nos que axiña falaremos polos problemas específicos que teñen.

A valoración do conxunto onomástico prelatino para coñecermos a lingua dos galaicos hai que facela á baixa, recordando que, por exemplo, para quen queira saber da lingua española hai máis e mellor información lingüística no Padrenuestro -texto típico dos catálogos de linguas- que en toda a restra de nomes e apelidos da guía telefónica de Madrid.

Para mostra de tendencias fónicas e de elementos morfolóxicos indíxenas abonde con DEIBABO NEMVCELAIGABO [Búa 2000: 396; Chaves TM], LVGVBO ARQVIENOBO(O) [IRPL 67, Sober LU], pero LVCOUVBV ARQVIENI(S) [IRPL 68, Outeiro de Rei LU]:

a) Betacismo en DEIBABO < ${ }^{*}$ DEIW-A-BHO.

b) Sonorización de xordas intervocálicas, con $*_{-} k_{-}>-g$ - no sufixo *-aiko-presente en NEMVCEL AIGABO e característico da Hispania occidental, e que temos en Callaicus > galego, en chairego, labrego, brañego... Samaniego, Casariego... ; no teónimo $L V C O U V B V$ temos a reacción hipercorrecta con c-polo -g- etimolóxico que temos en $L V C O U V B O$, e ambos son unha mostra máis do coñecido teónimo celta Lugus, pl. Lugoves, irl. Lug, etc., dunha raíz indoeuropea $*_{\mathrm{L}}(\mathrm{E}) \mathrm{UG}(\mathrm{H})$ - e de etimoloxía discutida ${ }^{3}$.

c) O dativo de plural indíxena, céltico, en -bo, no canto do latino -bus, e ambos de ide. *-b(b)o(s); pero tamén o dativo xa latino ARQVIENIS no canto do céltico $A R Q V I E N O B O(O)$. Nótese que na lingua gala tamén temos -bo, pero na celtibérica hai -bos.

\subsection{Onomástica indíxena en autores gregos e latinos}

Unha boa colleita de onomástica prelatina, sobre todo etnonimia, toponimia e hidronimia, témola nos autores gregos e latinos que trataron cousas de Hispania e concretamente de Lusitania e

\footnotetext{
3 Hai outras opcións que non podemos discutir agora para o par LVCOUVBV/LVGVBO, opcións que prefiren o ide. ${ }^{*} \mathrm{~L}(\mathrm{O}) \mathrm{UK}$ - 'luz', e, polo tanto, será orixinaria -c- e secundaria $-g$ -
} 
Gallaecia: Apiano, César, Estrabón, Mela, Plinio o Vello, Ptolomeo, Xustino... e os itineraria de viae e mansiones e outros escritos xeográficos, que nalgún caso son pouco de fiar ${ }^{4} . \mathrm{Na}$ conta negativa destes autores gregos e latinos, e para completarmos o déficit no que falamos verbo da ausencia de textos bilingües latino-indíxenas, hai que pór:

a) A manipulación formal e etimolóxica que fan ou dan por boa nun material indíxena propicio para os mitos e tradicións de heroes troianos e gregos nas nosas costas e fundadores de cidades (Anfíloco en Ourense, Teucro en Pontevedra, Diomedes en Tui, Ilia en Iria, etc.). Estrabón, Plinio o Vello, Silio Itálico, Xustino, Diodoro Sículo, etc. son os máis significativos nunha tradición que, coa sanción de Isidoro de Sevilla, vai chegar ás crónicas da Idade Media e mais a xogos da erudición renacentista, falsarios, trapisondas xenealóxicas, etc. Un exemplo fermoso do que dicimos é a conversión da que rematou sendo beneficiario xa en tempo antigo o río Limia,

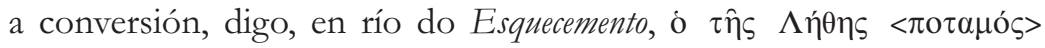
(Estrabón 3.3.4), flumen Oblivionis (Floro 1.33) e que, segundo Guerra (1996), corresponde máis ben ao actual río Lȩ̣a, afluente do Douro xa en Porto, é dicir, un *LETIA que foi asociado co nome grego $\lambda \eta \dot{\theta} \eta$, léthe, 'esquecemento', quizais con outros elementos mítico-relixiosos coma coadxuvantes; véxase García Bellido (1948), Guerra (1996), Moralejo, J. J. (2000a, 2000b, 2002), Untermann (inédito) ${ }^{5}$.

4 Refírome a cousas como a Ravennatis Anonymi Cosmographia, xa serodia e un tanto confusa no que transmite; por exemplo, nos hidrónimos hispanos Iberus, Medulla, Tagus, Baetis, Samus, Bibesia, Clerum, Nabum, Hade, Minua pódense recoñecer máis ou menos ben os actuais Ebro, Tajo, Guadalquivir, Miño, e tamén están, seica, Bibei (??) e Navia; pero hai outros tres dos que non teño criterio de identificación. Non considero aquí o nome de Avieno e a Ora maritima, do século IV d. C., pero que recolle, seica, material moi anterior, ademais do que inventa ou fantasea. Sería mellor que o traballo de investigación e de divulgación nas antigüidades da Gallaecia deixase fóra de consideración todo o vello conto dos celtas Saefes ou 'serpes'. Falo soamente no eido filolóxico e lingüístico, non no cultural, e o que haxa de ofiolatría na Gallaecia non perde nada -e quizais algo gañe- con deixar en paz o texto de Avieno.

5 Non me resisto a extractar e arranxar Gaspar de Barreiros (1561), «porque se quisermos buscar á interpretaçã dos vocabulos Hebraicos em os Gręgos, ou dos Gręgos nos Latinos, nunca nos faltarã que dizer, polla semelhança que tem hũs vocabulos cõ outros, como muitos fezerã interpretando... Tarragona em lingoa Armenia ajuntamento de pastores, \& outros na Latina, terra agonum... A Setuual cidade de Tubal. A Lisboa 
b) O seu desinterese polas linguas bárbaras e polas súas palabras -malsoantes e mesmo asemánticas-, mentres si informan noutros aspectos culturais, inda que ás veces cun interese nesgado, de xustificar a dominación política como vía para que a barbarie entre polos camiños da paz e mais da civilización (cf. Estrabón 3.3.8). No desinterese polas linguas bárbaras destacamos:

\section{Estrabón, Geographiká 3.3.7}

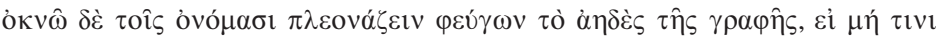

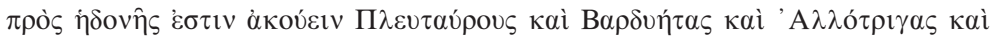

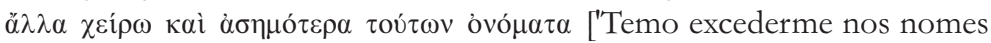
porque refugo o desagradable da súa grafía, a non ser que a alguén lle agrade escoitar pleutauros, bardietas, alótrixes e outros nomes máis feos e máis inintelixibles que estes'].

\section{Mela, Chorographia 3.15}

Cantabrorum aliquot populi amnesque sunt sed quorum nomina nostro ore concipi nequeant ['Hai entre os cántabros algúns pobos e ríos, pero os seus nomes son impronunciables na nosa boca'].

\section{Plinio, Naturalis Historia 3.5}

...ex his digna memoratu aut Latio sermone dictu facilia ['...entre estes <oppida béticos> dignos de mención ou fáciles de dicir en lingua latina'].

de Vhyses \& de Bona sua filha. A Tunes por cuidarem que fora edificada despois da destruiçam de Carthago, diriuâram d'estas palauras latinas Tu ne es? como que os velhos se espantauam vẽdo á desigualdade de hũa \& da outra... com outras mil vaidades em que nom falo, porque manifestamente se mostra á ignorancia dos que cuidâram ter sciencia de antiguidades, como Tullio [De nat. deorum 3.62.11] ia no seu tempo reprehendia este modo de diriuar vocabulos dizendo Quoniam Neptunum a nando appellatum putas, nullum erit nomen quod non possis vna litera mutata explicare vnde ductum sit, <in quo quidem magis tu mihi natare visus es quam ipse Neptunus $>$ » ['Xa que pensas que Neptuno recibe nome de nadar, non vai haber nome que con lle cambiar unha letra non poidas explicar de onde vén, e niso parécesme nadar ti mais do que Neptuno mesmo'].

A manipulación e 'peneira' fono- e morfolóxica e tamén etimolóxica da onomástica dunha lingua ao ser integrada noutra non necesita obxectivos histórico-culturais específicos e abonda coa mera semellanza formal para as máis inesperables adaptacións: o topónimo burgalés Castrogeriz é Quatre Souris (jcatro ratos!) en textos medievais franceses. O humanista Nonio supuña que os suevos xermanizaran as Aquae Cal(i)dae nunha Warm See da que ipor corrupción! resultou Ourense. O azteca Cuauhnábuac foi adaptado a Cuernavaca. 
Plinio, Naturalis Historia 3.28

Lucensis conventus populorum est sedecim, praeter Celticos et Lemavos ignobilium ac barbarae appellationis,... Simili modo Bracarum XXIIII civitates CCLXXXV capitum, ex quibus praeter ipsos Bracaros $<$ B $>$ ibali, Coelerni Callaeci, $<\mathrm{E}>$ quaesi, $\mathrm{Li}<\mathrm{mi}>\mathrm{ci}$, Querquerni citra fastidium nominentur ['O convento lucense ten dezaseis pobos, agás célticos e lémavos, descoñecidos e de nome bárbaro... Así mesmo o dos brácaros $<$ ten $>$ vintecatro cidades e douscentos oitenta e cinco mil homes, e deles citaremos, sen chegarmos ao fastío, ademais dos brácaros, os bíbalos, celernos calaicos, ecuesos, límicos, cuercuernos'].

En fin, os lingüistas somos os que máis saímos perdendo nas fontes dunha romanización que é sinónimo de latinización, mentres é consentidora e mesmo integradora e sincretizadora noutros campos da actividade cultural e social do romanizado, campos nos que Estrabón, Plinio, etc. son máis curiosos e saben que tamén o somos nós.

\section{Problemas DE EDICIÓN E INTERPRETACIÓN}

Untermann ten chamado repetidamente a atención (por exemplo, 1985: 343; 1992a: 369) sobre os epígrafes que pola natureza dos seus soportes, pola súa conservación imperfecta ou parcial, pola súa mala letra, etc. non permiten lecturas seguras nin interpretacións e conclusións firmes; o risco de erro é maior no caso dos hápax legómena, que non deben ser aceptados, se non hai certeza plena na súa lectura. Tamén hai dificultades no feito de dispormos de epígrafes con texto curto e formulario, sen contexto extralingüístico amplo e seguro que sexa axuda para hipóteses etimolóxicas que poden ter máis de antollo ou de exercicio individual de enxeño que de contribución ao coñecemento común e obxectivo, hipóteses sen consistencia suficiente para se proxectar a ser soporte de coñecementos certos en relixión, mitoloxía, organización social, etc. dos nosos antepasados ou, peor aínda, hipóteses que poden xerar un auténtico círculo vicioso no que A é certo se é certo B e B é certo se é certo A, que é certo se é certo B... Estamos limitados a un corpus textual facareño, absolutamente cativo en léxico común que sexa garantía da hipótese etimolóxica que facemos cando eses nomes comúns xa son propios, son onomástica: 
esta é a nosa principal eiva, inda que nalgúns casos nas outras áreas hispánicas ou europeas teñen documentación que asegura ou mellora a interpretación da nosa. Cando agora temos os topónimos Carballo ou Valverde del Fresno, a análise é segura polos comúns carballo, vall valle, verde e fresno ${ }^{6}$, pero cando estamos diante de Tamaris/Tambre as cousas xa son problemáticas, inda que teñamos un mangado de referencias comparativas e non andemos ás puras apalpadas. No estado actual dos nosos estudos cómpre pelidar por unha maior atención de todos ás esixencias do método filolóxico e lingüístico para non irmos dar nun agravamento dos déficits nos que estamos a falar.

E velaí algúns exemplos do que levamos dito neste apartado.

1. No epígrafe lisboeta editado por Encarnação (1975: 91), C S/ APONLANICO/POLISCINIO/SACRUUM/A L os presuntos teónimo + epíteto Aponianico Poliscinio, dous hápax legómena, parecen ser, se seguimos a lectura e interpretación de Pflaum (1950: 36) e Untermann (1985: 345), o nome da dedicante Aponia Nicopolis e o dativo Genio, receptor da dedicación.

2. En IRG IV 93 (Mosteiro de Ribeira, Xinzo, OU), REVE VEISVTO (O VEISVTO), a forma VEISVTO ten sido obxecto de interpretacións tan diverxentes como:

a) epíteto, con etimoloxía varia, do teónimo REVE;

b) forma verbal de voz media, desinencia -to, equivalente a dedit, donavit dos epígrafes latinos;

c) grafía errada do formulario ex voto.

A mellor opción é, seica, (a) polo que é o epígrafe en conxunto de texto e contexto.

3. Nunha ara atopada en Santo Ourente de Entíns (Outes C), Millán (1971 e 1973) quere que o galeco *RU(G)Ós, 'fozador > xabarín', estea en dativo de singular xa latino nas letras RVO, que moi probablemente son, coa $P$ precedente, abreviatura de $P R(o) V O(t o)$. En calquera caso nin texto nin contexto autorizan en absoluto a hipótese.

4. O IRG IV 91 (Mosteiro de Ribeira, Xinzo, OU) é epígrafe, hoxe perdido, que o Padre Sarmiento leu CROVGIN TOVDADIGOE RVFONLA $\operatorname{SEVER}(A)$. Con tal lectura pódese entender:

\footnotetext{
${ }^{6}$ Pero xa non é nada segura a transparencia dos enganosos Valdoviño ou de Vía de la Plata.
} 
a) CROVGIN, de *KROUK-, como acusativo de singular, a pedra (jo croio!) que se consagra á divindade TOVDADIGOE, 'comunal ou nacional', é dicir, un adxectivo derivado do substantivo indoeuropeo occidental *TEUTÁ 'comunidade, pobo, nación', *TEUT-AT-IKOs (cf. etnónimo galo Teutatis), con sonorización $*_{-t-}>-d-$, con $*_{e u}>$ ou e caso dativo *-oi coa grafía -oe.

b) Pero, se seguimos a boa suxestión por Gorrochategui (1987: 87) de que CROVGIN poida ser CROVGLAI, dativo de singular, con ligadura de $-A I$ que Sarmiento non recoñeceu, teremos o sintagma frecuente teónimo + epíteto, ambos en dativo, CROVGLAI TOVDADIGOE. O teónimo CROVGLAI, a 'rocha ou penedo', ben documentado noutros epígrafes, cualifícase como TOVDADIGOE, 'comunal, nacional'.

c) Pero tamén é posible que TOVDADIGOE sexa o teónimo Teutatis, ben coñecido na Galia (na tríade Esus, Taranis, Teutatis, cf. Lucano, Farsalia I, 444-446) e tamén remisible a ide. *TEUTĀ, no dativo TOVDADI e coordinado ao teónimo CROVGLAI pola enclítica átona -GOE, grafía para o que na orixe indoeuropea formulamos ${ }^{*} K^{\mathbb{W}} \mathrm{E}$ e que atopamos nos textos celtibéricos coma -cue e ilustramos coa lingua latina en sintagma tan coñecido coma senatus populusque Romanus. Segue en pé que hai sonorización de xorda $k$, pero agora temos grafía $-O E$ con -o- para o elemento labial da oclusiva labiovelar $k^{w}$ ou da súa evolución no ámbito galaico?

Repárese nas profundas diferenzas entre as opcións que unha boa análise filolóxica e lingüística permite, pero sen que ningunha se impoña como definitiva.

5. O texto lusitano MLH IV L.3 (Cabeço das Fráguas, Guarda) rexistra, seica, algo similar ao que os romanos chamaban suovetaurilia, un sacrificio de animais de diferentes especies. Desde que foi coñecido o texto ten ampla aceptación a interpretación que fixo Tovar (1973: 189) de TAVROM IFADEM coma 'touro semental', con remisión a ide. ${ }^{*}$ YEBH- que os dicionarios definen pudicamente co latino futuere. Recentemente Prósper (2004: 175) propón IFADEM <

\footnotetext{
Non é miña e non podo recordar de quen é esta segmentación en teónimo TOVDADI + enclítica GOE. En MLH IV L.2.1 (Lamas de Moledo) Untermann conxectura que MACAREAICOI sexa MACAREAI + enclítica-COI.
} 
* $\mathrm{H}_{1}$ EN-BHATYOM 'que truca, bravo' (cf. lat. battuo 'bater'), etimoloxía que tamén é moi plausible.

Sen entrarmos en detalles menores das dúas etimoloxías, ambas teñen o obstáculo de que IFADEM é un caso illado e a comparación xenética soamente ten por válida a regularidade deducible dunha pluralidade de casos e foxe da singularidade non probatoria. IFADEM é a andoriña que non fai primavera: as etimoloxías de Tovar e de Prósper son certas se previamente é certo que houbo ${ }^{*} b h>f$ e este $* b h>f$ é certo se as ditas etimoloxías son certas... Nestes casos cómpre lembrarmos o noso cantar de que unha perna (non) tapa a outra.

De toda importancia é que as dúas etimoloxías supoñen unha evolución ide. ${ }^{*} b h>f$ que non encaixa no esperable nunha lingua céltica, que tería $* b h>b$, e, polo tanto, este resultado $-f$ - pódese sumar a outros feitos que despois veremos na discusión de que a lingua lusitana non é céltica (Tovar, Prósper e moitos outros), pero ten elementos ou infiltracións célticas. Pero téñase en conta xa desde agora que os resultados $*_{b h}>b$ e ${ }^{*} g h>g$ son seguros nos nomes con *BHRGH- > Brigantium, Avobriga, Aviliobris... e tamén hai exemplos seguros ou conxecturais para $* d h>d$, mentres que este e outros de $* b h>f$ son conxecturais.

6. Tamén no texto do Cabeço das Fráguas temos unha ICCONA LOIMINNA que pode ser teónimo + epíteto. A relevancia do cabalo no mundo cultural indoeuropeo en xeral e céltico en particular levou a, por exemplo, Maggi (1983: 58) a ver en Iccona a equivalente lusitana da deusa gala Epona, teónimo derivado de ide. *EKWOs 'cabalo'.

A hipótese foi atractiva e produtora dalgún papel entre non lingüistas para falaren do cabalo no mundo cultural e relixioso da Lusitania, pero o caso é que Iccona tería unha evolución $*_{-}-k w$ - > -cc- incompatible coa que temos noutros datos galaicos, lusitanos e hispánicos en xeral, por exemplo, Equaesi, Equotullaicensi, Equabona ou Aquabona, Aquis Querquernis... que manteñen ide. *kw e * $k^{\prime \prime}$, é dicir, poñen o céltico hispano no ámbito conservador do Celta- $Q$, non no innovador do Celta-P (cf. galo Epona $<{ }^{*}$ EKWO-NA), no que, madía leva, tampouco encaixaría Iccona, que tería algún paralelo ou, mellor, coincidencia

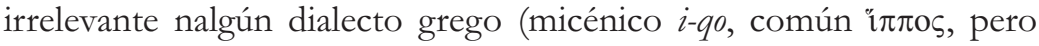

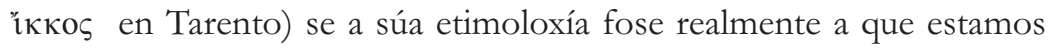
comentando, a do cabalo, e non, como parece máis viable, a do ide. *YכK- 'curar, sandar'. 
Dentro do ángulo noroeste que delimitan Pisuerga, Tormes e Tejo temos varios epígrafes nos que un dativo REVE é, seica, teónimo e acompáñase de epítetos que son claramente de xénero gramatical masculino (por exemplo, Paramaeco, Anabaraeco, Siddico, Veisuto, Vestero, etc.). O erro veterano de supor desde o dativo Reve sen o debido fundamento un nominativo feminino Reva dobrouse con esquecer o xénero masculino dos epítetos e rematou nunha deusa Reva da que se conxecturou etimoloxía e conexión coas chairas, etc. e todo iso adobiado con presuntos paralelos mitolóxicos e relixiosos irlandeses. Velaí un excelente exemplo de como a desatención a unha análise gramatical básica pode comprometer o que se faga noutras áreas de coñecemento.

E para REVE temos tamén outras etimoloxías - por exemplo 'río' (Villar 1996b), ou un xenérico 'deus' (Búa 1997; Witczak 1999)-, etimoloxías que non teñen seguridade plena polo que poidan significar os epítetos acompañantes e mais polo que informen o contexto lingüístico e extralingüístico dos epígrafes en cuestión.

En fin, co que levo dito quero suxerir que nas chamadas Trümmersprachen ou linguas en cascallos reducidos a onomástica o principal e máis seguro do traballo está nos inventarios e análises formais e soamente nalgúns casos os datos en si mesmos ou, mellor, en pluralidade sistemática e con axuda da comparación lingüística e mais do contexto extralingüístico, fan segura a interpretación étimo-semántica e as conclusións que se poidan derivar dela.

Pero tamén pode haber problemas en se a etimoloxía do teónimo, epíteto ou calquera outro nome é ou non é indicio válido da entidade, atributos, funcións, etc. do seu portador na data e no lugar en que eses nomes se nos documentan ou nos leva a tempos, lugares e condicións sociais e culturais distantes e diferentes. Por exemplo, recórdese que hai moitos séculos que os pontífices non fan pontes.

\section{BREVE HISTORIA DA CUESTIÓN}

Unha mellor atención a Estrabón, Geographiká 3.1.6,

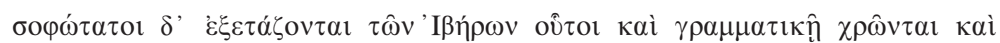

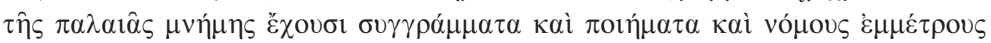




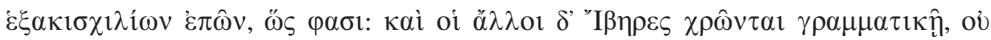

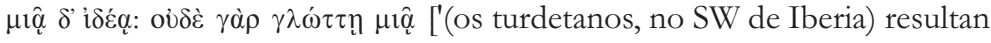
ser os máis ilustrados dos iberos e teñen escritura, rexistros escritos do pasado, poemas e leis en composicións de seis mil versos, segundo din, e os demais iberos utilizan a escritura, pero non nunha soa forma, pois tampouco non teñen unha soa lingua'],

e tamén facer outra valoración da supervivencia da lingua vasca fronte á latinización aforraríannos séculos de vixencia do estado xeral de coñecementos, e tamén de antollos e trapalladas, que na lingüística rematou na que Caro Baroja (1942) chamou hipótese vasco-iberista, é dicir, supor para toda $I_{\text {beria }}^{8}$, toda a Península, unha unidade lingüística ibera da que sería hoxe supervivencia a lingua vasca. En 1821, cando bota a andar con paso firme a lingüística histórica e comparada coa novidade indoeuropea, o prestixio de Wilhelm von Humboldt e a súa Prüfung der Untersuchungen über die Urbewohner Hispaniens vermittelst der Vaskischen Sprache (Exame das investigacións sobre os habitantes primitivos de Hispania por medio da lingua vasca) ${ }^{9}$ consolidan para un século longo o vasco-iberismo, continuador dunha longa tradición erudita e polémica na que son nomes ilustres Juan de Valdés, Garibay, Poza, Larramendi, Conde, Mayáns, Astarloa... e da que fixo Tovar (1980) excelente crónica.

Abonda coas dúas primeiras conclusións de Humboldt para entender o estado de cousas:

1. Die Vergleichung der alten Ortnamen der Iberischen Halbinsel mit der Vaskischen Sprache beweist, daß die letztere die Sprache der Iberer war, und da dies Volk nur eine Sprache gehabt zu haben scheint, so sind Iberische Völker und Vaskisch redende gleichbedeutende Ausdrücke [é dicir, 'a comparación dos topónimos antigos da Península Ibérica coa lingua vasca proba que esta última era a lingua dos iberos e, como este pobo soamente tivo, seica, unha lingua, resulta que pobos ibéricos e pobos de lingua vasca son expresións equivalentes'].

8 No coñecemento progresivo que o comercio fenicio, púnico e grego tivo da Península o nome de Iberia corresponde á costa leste e sueste e o seu binterland, o nome de Tarsis ou Tartessós refírese ao ángulo SW, e Keltiké alude ao interior da Península. Nas fontes gregas Ibería acaba sendo nome de toda a Península, a Hispania dos textos latinos; pero o que imos ver é que Iberia, ibero, ibérico ten que se limitar á área étnica, lingüística e cultural do E e SE da Península. Véxase Koch 2003: 201.

9 Hai traducións, Primitivos Pobladores de España y Lengua Vasca, Madrid 1959, e Los Primitivos habitantes de España, Madrid 1990. 
Humboldt, bo coñecedor dos textos clásicos e do material onomástico hispano, tamén tiña que recoñecer marxes ou substratos célticos, sobre todo en Celtiberia, Gallaecia e Lusitania:

2. Es giebt aber unter den Ortnamen der Halbinsel andre, von welchen die Vergleichung mit der Ortnamen der von Celten bewohnten Länder zeigt, daß sie Celtischen Ursprungs sind, und daß diesen lassen sich die Wohnsitze der mit den Iberern vermischten Celten auch da auffinden, wo uns die geschichtlichen Zeugnisse verlassen [é dicir, 'pero entre os topónimos da Península hai tamén outros cuxa comparación cos topónimos das terras habitadas por celtas indica que son de orixe céltica e que con eles pódense tamén atopar os asentamentos dos celtas mesturados cos iberos alí onde as testemuñas históricas nos abandonan'].

Soamente a fins do s. XIX cos estudos de D'Arbois de Jubainville na Revue Celtique se recoñece a forte e ampla pegada histórica e lingüística de Les Celtes en Espagne, inda que a liña dominante é a vasco-iberista de Humboldt (nótese o singular en Hübner 1893), Schuchardt, Schulten... Neste contexto de unidade e protagonismo ibéricos inscríbese que no recanto céltico que se presupón que é Gallaecia se traballe cos criterios e obxectivos de Murguía, Verea, etc., se faga a poesía de Pondal, Curros e Cabanillas, a leria de Vicetto e a teoría nacionalista de Risco, Otero, etc.

A partir de 1922 os traballos de Gómez Moreno (1949) e dos seus continuadores son unha enorme fe de erratas na lectura dos textos ata entón ibéricos, pero que tarda en se abrir paso contra o prestixio xermánico do vasco-iberismo e mais polos atrancos da nosa Guerra Incivil e a Mundial. Para proba de en qué grao alterou Gómez Moreno a lectura da documentación, compárese a edición da tessera celtibérica de Luzaga en Hübner MLI XXXV e en Untermann MLH IV, K.6.1:

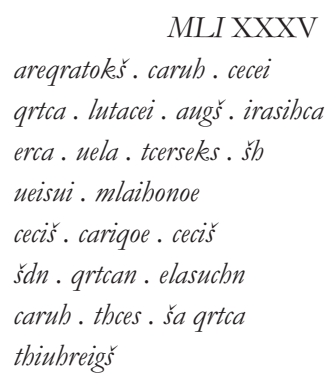

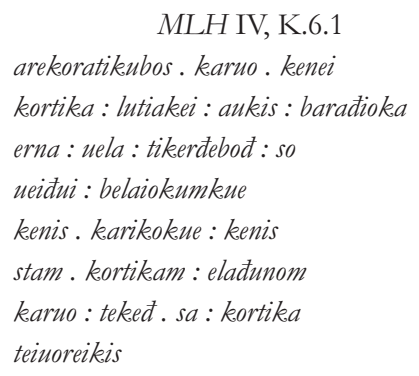


A nova lectura, a correcta, das escrituras indíxenas bota abaixo moito e moi esencial do traballo anterior e, sobre todo, cos estudos de Gómez Moreno, Schmoll, Tovar, Caro Baroja e outros vai dar no recoñecemento dunha pluralidade de sistemas de escritura -tartesa, ibérica e unha adaptación do alfabeto grego- e dunha pluralidade lingüística, sen paralelo coa de escrituras, que na documentación directa e na súa prolongación na indirecta (onomástica indíxena en autores gregos e latinos e/ou viva hoxe) articulamos en tres áreas, con repartición no que Untermann (1961) bota man de tipos onomásticos representativos delas:

1) Área tartésica, no SW, non indoeuropea e caracterizada polos topónimos con elemento final -ippo, -uba e outros (por exemplo, Olisippo(na), Corduba, Onuba... hoxe Lisboa, Córdoba, Huelva).

2) Área ibérica, no E e SE, non indoeuropea e con topónimos compostos con Ili-, Iltu-... que significa, seica, 'vila, cidade' e non parece alleo ao que temos nos topónimos vascos Irún, Iribarri... No mapa ibérico son bos exemplos Ilíberis, nome antigo de Granada, e Iltirta ou Ilerda, hoxe Lleida ou Lérida.

3) Área indoeuropea, no N, NW, W e centro da Península, con topónimos nos que destaco os compostos con segundo elemento -briga, -brix, -bris (jos nosos -bre e variantes -be, -ve) para dar nome á 'altura' habitada: Segobriga, Nemetobriga, Arcobriga... Da mesma raíz brig- o noso Brigantium e os Brigantini. Destaco tamén a raíz seg-, 'poder, forza', de Segovia, Segisamo (hoxe Sasamón; quizais o actual Sésamo dos Ancares de León), varias Segontia (hoxe Sigüenza), etc.

A documentación directa en escrituras ibérica ou latina da lingua celtibérica, lingua indoeuropea céltica, e a documentación directa en escritura latina da lingua lusitana, lingua indoeuropea de filiación discutida, veñen demostrar que a indoeuropeización de Hispania foi antiga, ampla e intensa. Se tivésemos que entrar nos aspectos ideolóxicos da erudición e da polémica pluriseculares, diríamos que perdeu forza aquilo de que África comeza nos Pireneos e que tiña un dos seus esteos na real ou suposta orixe norteafricana dos iberos. Nestes momentos a lingua celtibérica é peza esencialísima -Bronces de Botorrita, tesserae hospitales, etc.- no coñecemento do celta antigo e a polémica da lingua lusitana agrávase con que todo o centro peninsular, Gallaecia, Asturica, toda a Lusitania do Tejo ata o Algarve e toda a Baeturia -área celtizada no SO, entre Guadiana e Guadalquivir- carecen de documentación directa. 
De 1945 en adiante temos os traballos de Gómez Moreno, Caro Baroja, Tovar, Mitxelena, Lejeune, Schmoll, Untermann, Albertos, Menéndez Pidal e moitos máis para recoller e interpretar os materiais, e con polémica no que respecta á filiación específica dos textos lusitanos e doutros materiais hispánicos indoeuropeos. Da vella hipótese vasco-iberista queda pouco: hai relacións evidentes entre as dúas linguas e que poderían ser mesmo xenéticas e non soamente de semellanza tipolóxica e de contactos e intercambios de elementos, pero co que sabemos de lingua vasca non podemos entrar nos textos en lingua ibérica nin ter estes na mesma función na que temos a latina para as románicas. Do (des)coñecemento que temos da lingua ibérica abonde con dicirmos que, a carón dunha boa descrición fonolóxica e de coñecementos seguros e abundantes na morfoloxía nominal, no que respecta a morfoloxía verbal e mais a dicionario xeral estamos só un pouquiño por riba de cero.

\section{INDOEUROPEIZACIÓN E CELTIZACIÓN ${ }^{10}$}

A distinción entre indoeuropeización e celtización témola que facer porque, como xa ficou apuntado máis atrás, hai polémica en se todo o material indoeuropeo hispánico encaixa ou non, e baixo que condicións, na póla céltica da árbore lingüística indoeuropea, ademais de que dentro de esa árbore indoeuropea, sen dúbida paleolítica e máis alá pola continuidade axiomática da linguaxe e das linguas, a póla céltica é unha cristalización recente e levar a etiqueta lingüística céltica a tempos anteriores ás Idades do Ferro e do Bronce sería un anacronismo comparable a, poño por caso, dicirmos que en Hispania non entrou a

${ }^{10}$ Antes de comezar estas cuestións quero dicir que nin o bic et nunc nin as miñas capacidades abondan para presentación e análise crítica dos contidos de Villar (2000), con proposta dunha indoeuropeización moi antiga e detectable en hidro- e toponimia. Se aceptamos esta indoeuropeización, a Hispania que as teses tradicionais teñen por non indoeuropea sería, paradoxicamente, a de indoeuropeización máis antiga, pero mesturada ou cuberta por compoñentes posteriores non indoeuropeos e indoeuropeos celtas, pois as súas áreas principais de implantación son as do NL e S da Península. Pero tamén son alcanzadas Gallaecia e áreas inmediatas. Véxase tamén o seu traballo en Bocchi/Ceruti (2001). 
lingua latina, senón que entraron as linguas románicas -catalá, castelá, galega...- nas que ela se escindiu en data tardomedieval ${ }^{11}$.

A cuestión ten o seu punto de arranque en que as linguas indoeuropeas non son orixinarias en ningunha área de Hispania, que é indoeuropeizada en data(s) prehistórica(s) a discutir, ademais de que tamén en tempo xa histórico teñamos datos ou memoria de movementos de poboación que encaixan nesa indoeuropeización/celtización. Cómpre dar aviso de que, cando nestes procesos prehistóricos de emprazamentos, expansións e captacións de linguas falamos de orixes e de orixinario, non facemos outra cousa que aludir ao límite dos nosos coñecementos histórico-comparados ou das nosas hipóteses reconstrutivas.

O punto básico no esquema explicativo tradicional é que na indoeuropeización do Occidente europeo o protagonismo (¿exclusivo?) é das linguas célticas, cuxa orixe centroeuropea articúlase nunha Urbeimat ou 'patria primitiva' indoeuropea na Europa centro-oriental, e velaí un resumo tradicional e autorizado: «III ${ }^{\mathrm{e}}$ millénaire: les peuples indoeuropéens, lointains ancêtres des Celtes, s'installent en Europe centrale et occidentale» (Kruta 2000: vol. XI). Polo tanto, en tese tradicional a indoeuropeización de Hispania debe resultar de movementos de poboación con orixe última centroeuropea e que se poden remontar a Calcolítico e Bronce ou ser xa do Ferro.

Todo o occidente europeo considérase indoeuropeizado en procesos nos que o movemento de poboación é parte axiomática, pero necesita do complemento doutros moitos e importantes factores para que se produza a indoeuropeización que aquí presentamos como feito estritamente lingüistico, sen entrarmos agora en que haxa tamén difusión e imposición doutros feitos culturais indoeuropeos dos que a investigación lingüística non sabe prescindir porque está afeita a botar man do rexistro arqueolóxico para detectar nel as fracturas e as fronteiras, as continuidades e as novidades, as áreas e liñas de expansión da cultura material que lle poidan ser indiciais das expansións étnicas ou (soamente) culturais

${ }^{11}$ Non podo discutir aquí que tamén poida ser anacrónica para tempo paleolítico a etiqueta de indoeuropeo e teñamos que falar de pre- ou proto-indoeuropeo. Para o tema de agora temos abondo con que indoeuropeo non pode ser un quilómetro cero neolítico, inda que así o pareza en certos esquemas de reconstrución nos que o Indoeuropeo Común (ou a parte do indoeuropeo histórico que leva a parte do león neste labor) vén definido por un léxico que corresponde a novidades culturais neolíticas. 
coas que asociar as expansións e asimilacións lingüísticas. Despois diremos algo máis neste arduo problema, que nin é arduo nin é problema para moitos que tanto na banda da lingüística como na da arqueoloxía non están polos labores de síntese e prefiren que cada conxunto de datos e métodos terme das súas limitacións e siga o seu propio camiño.

Nos primeiros estudos da penetración céltica centroeuropea en Hispania tiñan especial relevancia arqueolóxica os enterramentos coñecidos como Urnenfelder ou 'campos de urnas', datables no Bronce e con implantación hispánica na área nordés e expansión ao val do Ebro; tamén entraban en conta os elementos culturais de Hallstatt (A e B, Bronce/C e D, Ferro) e, en menor medida, os de La Tène (Ferro). Nesta liña de traballo, que chega ata os manuais universitarios recentes, destaco os nomes de Bosch Gimpera, Santaolalla, Almagro Basch... e conecto os de Cuevillas, Bouza Brey...

Pero hoxe está en descrédito, seica, a orixe centroeuropea da nosa indoeuropeización/celtización asociada cos campos de urnas, cuxa paradóxica e principal implantación está nunha área que historicamente é de lingua e cultura ibéricas, non indoeuropeas. Tamén o rastrexo dos elementos hallstátticos e posthallstátticos é insuficiente, seica, para dar conta cabal da indoeuropeización centrada nunha inmigración de falantes recoñecible no rexistro arqueolóxico e capaz de se impor lingüisticamente por riba da poboación aborixe. Máis insuficientes aínda son os elementos latenienses, poucos, necesariamente recentes e que ademais, postos a xogarmos aos paralelismos de lingua e cultura, parece que terían que se acompañar dunha lingua céltica de tipo galo, un Celta- $P$, non o celtibérico e o panhispánico Celta- $Q^{12}$. Pero o importante en todo isto é a posición escéptica ante os migracionismos, sobre todo os invasionismos, e mais tamén ante a asociación de lingüística e arqueoloxía. O escepticismo fai insistencia en que Urnenfelder, Hallstatt e La Tène poden estar presentes en Hispania por tráfico cultural alleo a movementos de poboación e mais a difusións e asimilacións lingüísticas.

${ }^{12}$ Deixo de lado feitos puntuais, interesantes pero non na nosa materia de agora, sobre a presenza en Hispania de galos (cf. Marco 2004): por exemplo topónimos coma o aragonés Gallur < [Forum] Gallorum, etc.) e elementos culturais con marca lingüística da súa orixe gala, por exemplo, o xa visto teónimo Epona. 
Para o territorio de Gallaecia e a súa indoeuropeización pódense cargar as tintas na inexistencia ou na insuficiencia de Urnenfelder, Hallstatt e La Tène no rexistro arqueolóxico e como indicio de inmigracións indoeuropeas, é dicir, na inoperancia das hipóteses baseadas en movementos de poboación desde sedes centroeuropeas. Ademais para Gallaecia e tamén para outras áreas hispánicas insístese moito nunha celtización múltiple, heteroxénea na natureza dos seus procesos, así como na variedade de contactos e achegas culturais atlánticos, mediterráneos, orientais, de xeito que a caracterización dos hispanoceltas vai estar moi principalmente no terreo lingüístico, e non na súa comunidade cultural interna ou cos outros celtas continentais e insulares (cf. Arenas 2002: 33). Despois intentarei facer ver que as culturas de Hallstatt e La Tène ademais serían referencias baixas para a cronoloxía na que cómpre enxerir o carácter indoeuropeo de Gallaecia.

Pero antes cómpre dicir algo verbo dos descréditos excesivos do movemento de poboación como factor esencial na configuración dos mapas lingüísticos, pois na experiencia histórica está que a xente se move e o seu movemento pode e adoita ter consecuencias lingǘsticas. Descréditos excesivos, digo, porque, por moitos que fosen os excesos do migracionismo, do invasionismo é de asociar difusións culturais con difusións étnicas e lingüísticas, o mapa lingüístico europeo rexistra consecuencias claras dos movementos de poboación célticos, xermánicos, eslavos, maxiares... ademais de que a helenización de Oriente e a romanización/latinización do Occidente tampouco non son alleas a movementos de poboación.

Diebold (1987:27) afirma que «entire spoken languages do not and cannot diffuse through space save in the mouths of (some of) their speakers. It is impossible to imagine a scenario in which a semiotic system as complex as natural language could be thus transmitted by diffusion alone», e sabemos tamén que a oposición total aos chamados migracionismo e invasionismo é un luxo que se pode permitir o prehistoriador, pero non o historiador, pois apunta ben Dobesch (1983: 226, n. 147) que «es is unrichtig, zwischen Urgeschichte und Geschichte einen methodischen Unterschied zu machen, für letztere Wanderungen gelten su lasen, für erstere nach Tunlichkeit nicht. Es gibt keinen inhaltlichen Unterschied zwischen den beiden Bereichen, 
jeweils als Ganzes genommen» [é dicir, 'é incorrecto facer unha distinción metódica entre historia primitiva e historia, de forma que para esta sexan válidas as migracións, pero non para aquela por cuestión de viabilidade'], porque (Ib.: 230) «Urgeschichte ist keine Methode, keine Periode; sie ist nicht ein Epochenbegriff, sondern ein bestimmter Quellenzustand» [é dicir, 'a Historia Primitiva non é un método, un período, un concepto de época, senón un determinado estado das fontes'].

Pero o problema está en identificar liñas de continuidade e de ruptura no rexistro cultural prehistórico (je tamén xa histórico!) que poidan ser fitos iniciais das novidades étnicas e/ou lingüísticas que soamente poderemos recoñecer como xa históricas. Advirte Anthony (1986: 300), que «the fact that we have few predictive models or theories capable of incorporating such [population] movements into a larger explanatory framework does not mean that they were unimportant, and any archaeologist who pretends that they did not occur is quite simple fooling him/herself».

A crise profunda, quizais esaxerada por algúns, da valoración dos movementos de poboación (migración, invasión e conquista) é en certo modo a penitencia dos indoeuropeístas polos desastres do mito da raza superior aria que en procesos de auténtica invasión/dominación se expande e impón as súas lingua e cultura nas poboacións sometidas. É crise que favorece as opcións indixenistas, continuistas e difusionistas na configuración dos mapas culturais e lingüísticos prehistóricos e a súa proxección histórica. Estas opcións emparéllanse co éxito da xenética de poboacións e os seus paralelismos (a gran escala) entre árbores xenéticas e árbores lingüísticas, entre distancias xenéticas e distancias lingüísticas.

Non podo deitar aquí outra cousa que un par de observacións mínimas: o campo que nos interesa a xenética establece unha comunidade antiga das poboacións da fachada atlántica e unha diferenza clara entre elas e as poboacións da Europa central, comunidade e diferenza que poden suxerir debilidade do modelo tradicional no que a celti(ci)zación lingüística da dita fachada tiña como base única ou principal un movemento de poboación desde áreas centroeuropeas, consideradas tradicionalmente como homeland dos celtas. Favorécese así, pero non se impón, a alternativa de que o berce orixinario dos 
celtas e máis da súa lingua inclúa tamén a fachada atlántica e, moi especialmente, as Illas Británicas, pero tendo sempre presente que as continuidades xenéticas non prexulgan continuidades lingüísticas no mapa europeo, suxeito de sempre a cambios lingüísticos (e culturais), con ou sen consecuencias na etnicidade, con ou sen movementos de poboación, e que poden pasar desapercibidos no mapa xenético ou ter un reflexo cativo en relación coas súas consecuencias; refírome en especial aos procesos de élite dominance e, en xeral, á existencia de centros de poder político e de prestixio cultural decisivos no espallamento dunha lingua por riba doutra(s) e sen que o mapa xenético experimente o menor cambio.

\section{UN ENFOQUE LINGÜíSTICO}

\section{1. É celta quen fala unha lingua celta}

$\mathrm{Xa}$ que estamos a falar nas linguas e partimos de que é indoeuropeo o que fala unha lingua indoeuropea, tamén diremos que é celta o que fala unha lingua céltica, inda que esta posición pareza simplista ou reducionista a máis dun. Sen que importen os outros datos naturais (sexo, idade, raza...) e culturais (clase social, relixión e ideoloxía, ocupación profesional...), agora imos botar man de dato e argumento estritamente lingüísticos. Recórdese o absurdo ou a inconsistencia que hai en falarmos de gramática protestante, ou de cerámica indoeuropea, ou de raza flexiva... mentres que english, hispano, lusofonia, francofonia... son etiquetas lingüísticas claras e operativas, inda que cubran unha diversidade racial, étnica, cultural... moi grande.

E no caso das linguas célticas é bo termos moi presente que, cando Lhuyd (1707) relanza o termo céltico (porque nin galo nin británico son suficientes ou de recibo naquel momento), a base é a comunida-

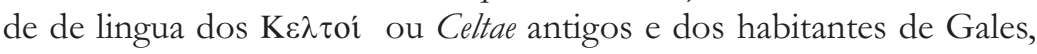
Cornéalles, Escocia, Irlanda, Mann e Bretaña en tempos medievais e modernos, comunidade que non se dá ou non é tan evidente nos outros eidos culturais do mundo céltico nin en perspectiva sincrónica nin en perspectiva diacrónica. 


\subsection{Indoeuropeo e substrato indoeuropeo}

Un dos criterios habituais para distinguirmos entre áreas indoeuropeas e áreas indoeuropeizadas é o de que nas linguas indoeuropeas das áreas indoeuropeizadas perviven restos preindoeuropeos, un substrato ben identificable no léxico común e na onomástica, pero máis ben escaso e problemático no terreo gramatical; tense dito moitas veces que o recurso ao substrato para cousas difíciles e o conto de querermos explicar obscura per obscuriora. O paradigma pode ser o da lingua grega antiga, na que unha cata no seu dicionario etimolóxico resulta en que máis da metade das raíces teña etimoloxía escura, é dicir, poida encaixar nese fondo preindoeuropeo pouco e mal coñecido ${ }^{13}$.

$\mathrm{Na}$ Gallaecia e noutras áreas hispánicas inmediatas rexístrase un substrato preindoeuropeo que ten etiquetado difícil e cambiante segundo métodos e obxectivos vixentes nas diferentes etapas da súa investigación. Eu penso que este substrato preindoeuropeo necesita unha revisión a fondo e pode e mesmo debe ser valorado á baixa porque:

a) Boa parte do seu léxico é fitonimia -amorodo, carqueixa, carrasco, codeso, mata, morango, queiroga, touza...-, é dicir, nomes de flora que, polo menos parte deles, poden ter a súa orixe na área mediterránea, sen dúbida non indoeuropea, e chegar ata nós como préstamos. E tamén habería que revisar se algúns deses nomes non foron do substrato, senón de selo indoeuropeo, pero locais ou dialectais na súa implantación.

b) Carecen do menor valor probatorio a efectos de comparación xenética os nomes que son onomatopeicos, por exemplo, cigarra, chicharra...

c) Como préstamos da área peninsular non indoeuropea, ibérica, tamén se poden considerar voces como veiga e algunha outra.

d) Para as datas prehistóricas que esta especulación pretende atinxir tamén pode ter algún relevo a nota de que na lista tradicional de nomes de substrato preindoeuropeo galaico non hai ou é moi escaso o léxico cultural, é dicir, de elementos de organización familiar e

\footnotetext{
${ }^{13}$ Pero téñase en conta que a produtividade das raíces do substrato é nula ou moi curta, mentres a das patrimoniais é grande, de tal xeito que no dicionario de palabras as de substrato son minoría.
} 
social, de ideoloxía e crenzas, de artes e técnicas, de vida económica... e todo ou case todo ese léxico (real ou supostamente) de substrato é natural, de nomes de plantas, do terreo e das súas formas, etc. Tense, xa que logo, a impresión de que, se houbo indoeuropeización, non se impuxo a formas culturais que deixasen a súa pegada na lingua nova e dominante. Alternativamente, non hai indoeuropeización, senón selo indoeuropeo orixinario, é dicir, desde os límites que alcanzan os nosos datos e as nosas especulacións reconstrutivas.

Non estou en condicións de negar o substrato preindoeuropeo que Gallaecia comparte, seica, con outras áreas hispánicas e mediterráneas, pero si quero pór de relevo a súa escasa entidade e a posibilidade de que boa parte del non sexa realmente substrato, senón dialectalismos no indoeuropeo occidental ou tamén os axiomáticos préstamos que toda lingua en contacto con outras áreas (ibérica, mediterráneas...) recibe delas: xa se ve que ando a imaxinar unha situación indoeuropea orixinaria de Gallaecia ${ }^{14}$.

Aínda máis, a revisión a fondo do substrato terá que se combinar coa revisión da reconstrución tradicional da Ursprache indoeuropea, baseada nas linguas centrais e orientais, e máis tamén coa revisión, a fondo e urxente, da Urheimat ou homeland indoeuropea e dos procesos de expansión ou indoeuropeización de áreas orixinariamente non indoeuropeas. Se cadra, parte do que temos por substrato pode ser un indoeuropeo occidental que para ser cabalmente indoeuropeo non necesita revalidarse nos léxicos indoiranio, grego, etc. bases da reconstrución tradicional.

\subsection{Hidronimia paleoeuropea}

A alteuropäische Hydronymie ou hidronimia paleoeuropea, á que Krahe consagrou desde 1949 unha chea de artigos e varias monografías (en especial 1962, 1964), é un subsistema onomástico indoeuropeo de raí-

\footnotetext{
${ }^{14}$ No modelo que ando a imaxinar o contacto lingüístico de Gallaecia con outras áreas podería chegar mesmo a mesturas en certas áreas galaicas con situacións de bilingüismo, diglosias, linguas francas... Recórdese que a mestura étnica e lingüística parece acreditada en datas da romanización pola onomástica e por datos extralingüísticos en áreas da actual Navarra e do val do Ebro, con vascóns, iberos e celtiberos.
} 
ces, sufixos e regras para formar os hidrónimos ou nomes de augas correntes e estancadas en Europa. É importante subliñar, con Schmid (1995, 1997) e mais con Untermann (1999), que os hidrónimos paleoeuropeos non teñen explicación suficiente na lingua das xentes que historicamente viven acaroadas a eles, pois pertencen a un sistema anterior ás linguas que foron callando dentro da comunidade primitiva indoeuropea, pero que é respectado polos falantes desas linguas.

Os hidrónimos paleoeuropeos cobren Europa desde os Urais ao Mar do Norte e Illas Británicas, desde o Mar Báltico ata os Alpes, e tamén están presentes nas penínsulas ibérica e italiana, é dicir, ocupan o territorio que en tempo histórico é das linguas eslavas, bálticas, iliria, xermánicas, itálicas e célticas; teñen tamén algunha presenza noutras áreas que historicamente son das outras linguas indoeuropeas. A raíces e os sufixos destes hidrónimos poden aparecer tamén en topónimos e o mapa hidronímico complétase con moitos outros nomes que xa non encaixan no paleoeuropeo, senón nas linguas indoeuropeas históricas: por exemplo, os nosos Avia, o medieval Alesantia, etc. son analizables como paleoeuropeos, pero os tamén nosos Deva e Dubra son célticos.

Ademais de indoeuropeístas que teñen un escepticismo total verbo da alteuropäische Hydronymie (por exemplo, Mallory 1989: 157 e n. 30), entre as críticas máis relevantes feitas ao sistema definido por Krahe está a sospeita de Scherer (1963), Lazzeroni (1964) e outros de que hidrónimos de aparencia paleoeuropea en áreas mediterráneas, concretamente Italia e Hispania, non sexan indoeuropeos, senón mera coincidencia ou homofonía de raíces monosilábicas e sufixos simples co material realmente indoeuropeo ${ }^{15}$. Pero se en Hispania e, o que agora importa, en Gallaecia e Lusitania, acumulamos exemplos de hidrónimos (Ave, Avia, Aguianza, med. Alesantia, Aranza, Argan₹o, med. Auania > A Baña, med. Alesgos $>$ Esgos, med. Aliste $>$ Este ...) e de topónimos nos que raíces asinables ao dicionario indoeuropeo se combinan con dous ou máis sufixos do repertorio indoeuropeo (por exemplo, ${ }^{*}$ TAM-AR-I-S $>$ Tamaris

${ }^{15}$ Téñase en conta que en boa parte as teses de Krahe son reconversión de vellas posicións sobre elementos non e pre-indoeuropeos de filiación ou etiquetado vario (mediterráneo, ligur, ambro-ilirio, ilirio...), por non dicir que nebuloso. Un curioso intento é o de Venneman (1994) que conclúe que os topónimos e hidrónimos paleoeuropeos (ipero non indoeuropeos!) e as linguas de lígures, iberos e vascos pertencen a un Old European cuxo único supervivente é a lingua vasca. 
$>$ Tambre, ${ }^{*}$ AL-IS-NT-YEH $2>$ med. Alesantia) e contamos ademais con paralelos ou similares en áreas de indoeuropeidade indiscutida, a homofonía casual vai excluída e a indoeuropeidade antiga, moi antiga, de Gallaecia e Lusitania parece fóra de dúbida.

Vou aludir un punto de vista -e non direi que tamén de método porque é absolutamente estéril- que teñen algúns prehistoriadores e arqueólogos, pero que non é posible en filólogos e lingüistas: vou aludir e desbotar o antollo de que a onomástica hispana prelatina, incluída a galaica, e especialmente hidronimia e toponimia, poida ter unha débeda relevante coas xentes non latinas -auxiliares, mercenarios, comerciantes...- que nos trae a romanización. Hipóteses de que lles debamos tal ou cal nome concreto poden ser de recibo, pero explicacións de sistema e do conxunto do material, ningunha en absoluto.

Porque o que de verdade importa é constatar a implantación sistemática dunha hidronimia -e tamén dunha toponimia-indoeuropea prelatina en Gallaecia, sen que nelas, sobre todo na hidronimia primaria, haxa unha pegada clara, abundante, sistemática dun estrato preindoeuropeo. A estabilidade ou persistencia dos hidrónimos, a pesar dos cambios étnicos, lingüísticos e culturais na poboación que vive nas ribeiras, é unha experiencia tan repetida que non necesita presentación. Velaí, pois, como a hidronimia paleoeuropea ten sempre un valor diagnóstico moi claro para a indoeuropeidade orixinaria das áreas nas que a rexistramos. Podemos pensar, polo tanto, nunha Gallaecia indoeuropea desde data moi antiga, poñamos que polo menos desde o Bronce, segundo milenio a.C., se non estamos en condicións de saber ou supor que por ter Gallaecia unha poboación moi escasa ata datas moi baixas, xa en plena Idade do Ferro, xa moi entrado o primeiro milenio a.C., foille posible a grupos reducidos de indoeuropeos inmigrantes impor a súa lingua tamén nese apartado de substituír todo o sistema hidro- e toponímico anterior. Teño entendido que o rexistro arqueolóxico non documenta nin tal escaseza de poboación nin as inmigracións suficientes para cubrir o territorio e operar a substitución do sistema hidro- e toponímico. Ademais, non ten a menor verosimilitude que, se a indoeuropeización lingüística nos chegase nun proceso de mera difusión/asimilación desde un centro extragalaico (¿ulo?), puidese operar a substitución do sistema hidro- e toponímico establecido. 
A énfase na antigüidade e mais na estabilidade cómpre facela no terreo hidronímico e quero sinalar que no moito que levo inventariado de hidronimia galaica prerromana non teño observado repeticións que parezan deberse a factores culturais ou modas que nos rebaixen a nota de antigüidade e sistematicidade con que Gallaecia é indoeuropea nos seus hidrónimos. Fagamos a reserva ¡madía leva! de que a indoeuropeidade dalgúns hidrónimos poida ser soamente aparente e que o preindoeuropeo teña tamén os seus dereitos, pois hai moitos hidrónimos curtos e simples nos que a análise decide pouco e non exclúe a xa aludida homofonía do que é indoeuropeo e do que non o é.

En cambio, nos topónimos, a carón da nota de antigüidade e de estabilidade que os fai arma esencial na definición de estratificacións e fronteiras de linguas e de pobos, está a experiencia frecuente de como tamén están suxeitos a mobilidade e produtividade por factores políticos e culturais diversos e, polo tanto, o seu mapa pode ocultarnos ou darnos unha imaxe incorrecta da situación orixinaria e das áreas e dos estratos desde entón ao tempo documental. Ninguén se vai confundir e supor iberos, celtas, árabes... no caso dos Toledo, Córdoba, Guadalupe, York, Ipswich, Marlborough... en América, Australia, etc., nin hai maior problema tampouco para entendermos o por que e o cando dos mixtos Caesarobriga, Iuliobriga, Flaviobriga hispanos, Caesarodunum, Augustodunum galos, etc., pero sería inxenuo termos o primeiro mapa toponímico posible coma reflexo real dunha traxectoria prehistórica carente de diferenzas no espazo e no tempo.

\section{4. 'Orixes' indoeuropeas}

A revisión que fixemos do pouco (?) substrato preindoeuropeo de Gallaecia e a impresión firme de termos un sistema hidronímico necesariamente antigo e claramente indoeuropeo lévannos a dicir catro cousas verbo das orixes indoeuropeas, é dicir como é a reconstrución da protolingua e do tempo e do espazo que se lle asigna nas teses máis en uso.

Teimando na estabilidade axiomática dos hidrónimos, sobre todo no caso das correntes de auga máis significativas polo seu caudal, lonxitude, relevancia económica, de comunicación, etc., parece que 
toda a Europa da alteuropäische Hydronymie é indoeuropea orixinaria (Kitson 1996 e 1997). Teño a impresión de que os mapas xenéticos non me levan a contraria en absoluto e mesmo están ao meu favor, inda que eu deba ter a honradez de advertir que nos meus criterios e datos non hai correspondencia necesaria, biunívoca, entre a difusión da agricultura neolítica e a indoeuropeización ${ }^{16}$, pero si é certo que a base xenética maioritaria da poboación europea é paleolítica.

Por outra banda, se aínda lle damos valor a certos criterios tradicionais, resulta que a chamada Paleontoloxía Lingüística -iEtimomancia segundo algún dos seus detractores! ${ }^{17}$ - non pon obstáculo decisivo para que, tal como xa teñen feito Makkay (1987 e 1992), Kilian (1988) e outros (cf. Kitson 1996, 1997), o territorio indoeuropeo orixinario inclúa xa en tempo paleolítico áreas occidentais europeas, e tanto polo que estas son como marco natural (flora, fauna, clima...) como polo que nelas hai no ámbito cultural. Penso que cómpre revisar o modelo tradicional dunha Urheimat ou homeland indoeuropea de situación ponto-caucásica e de datación neolítica, pois é modelo con protagonismo excesivo do indoeuropeo centro-oriental, é dicir, a área que vai dar nas linguas anatólicas, grega e indo-iranias... e tamén modelo que, centrado na discusión das formas culturais indoeuropeas xa serodias, neolíticas, da chamada tradición cultural dos kurganes (ou mámoas, túmulos) e da cerámicas de cordas, etc. dá unha imaxe (parcial) dos últimos tempos de lingua común e primeiros de dispersión e fragmentación lingüística, pero non entra na profundidade paleolítica que a familia indoeuropea ten e quizais peca de reducila a uns marcos espaciais e culturais estreitos.

$\mathrm{O}$ argumento da hidronimia paleoeuropea e da ausencia ou escaseza de substrato preindoeuropeo suxiren esta ampliación, que non pode ser confirmada, pero tampouco non é impedida, polas liñas de continuida-

${ }^{16} \mathrm{Na}$ improcedencia de deitar títulos e títulos, limítome ao colectivo Bocchi/Ceruti (2001), con contribucións de Renfrew, Cavalli-Sforza, Mallory, Villar e outros.

17 A paleontoloxía lingüística considera que a reconstrución dun léxico indoeuropeo común prehistórico prolóngase na reconstrución das circunstancias naturais e culturais nas que viviron os falantes dese léxico. A obxección principal que se lle fai é que o léxico é o elemento máis cambiante e con menor regularidade no sistema da lingua, e na maior parte dos casos por causas extralingüísticas, alleas ao sistema da lingua. No que portén ás circunstancias culturais é evidente que a reconstrución ten que estar aberta a mil variacións no espazo e, sobre todo, no tempo. 
de e descontinuidade do mapa xenético europeo. Pero o punto principal da miña posición é que ando un pouco de volta dos optimismos de establecer correspondencias claras entre lingua e cultura material para proxectarmos ao tempo prehistórico, predocumental, o que temos no xa histórico. Agora o que teño claro é máis ben que lingua e cultura (material ou non) poden e adoitan ser magnitudes sen correspondencia recíproca necesaria, e que a continuidade ou estabilidade da tradición lingüística é máis grande que a das tradicións culturais.

Unha consecuencia importante do que levamos conxecturado e proposto ata aquí é que a reconstrución do indoeuropeo común prehistórico non pode ter como modelo experiencias históricas como as dos pequenos recantos que foron o berce do latín, do inglés, do castelán, do portugués e outras linguas que coñeceron unha expansión territorial e poboacional xigantesca en comparanza cos comezos. Penso que as moi notables variacións dialectais que temos na gramática e no léxico indoeuropeos históricos tamén suxiren unha área orixinaria grande na que, seguindo esquemas de Hockett (1962: 321), a lingua nai indoeuropea é unha macrolengua de microlenguas constituídas por idiolectos.

\section{5. 'Orixes' indoeuropeas de Gallaecia}

O espazo indoeuropeo ampliouse axiña cara á Asia Menor, Irán e India, Turquestán (linguas anatólicas, indoiranias, tocaria), e tamén cara ás penínsulas balcánica e itálica; nesa ampliación os movementos de poboación tiveron protagonismo certo. É moi posible que a presenza indoeuropea sexa orixinaria nas áreas europeas occidentais, Illas Británicas incluídas, e insisto na miña convicción de que boa parte de Hispania -incluídas Gallaecia e Lusitania- pode ser indoeuropea orixinaria ou desde datas antigas como para anular ou pouco menos o antecedente non indoeuropeo. En particular quero insistir na absoluta insuficiencia lingüística de todo modelo de etnoxénese hispánica na que a indoeuropeización/celtización de Gallaecia veña encomendada a movementos étnicos e de difusión cultural desde a Celtiberia xa constituída, é dicir, a partir dos séculos VII-VI, Idade do Ferro. Hai presenza antiga de celtas en Hispania, hai movementos desde Celtiberia a outras áreas hispánicas e sabémolos ou deducímolos polos textos de: 
a) Heródoto, Istoríe, sobre celtas que, se a noticia admite unha interpretación simple e certa, hai que situar no Sudoeste, na que despois será Baeturia:

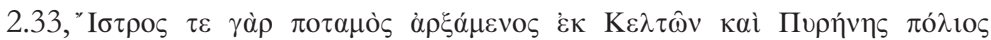

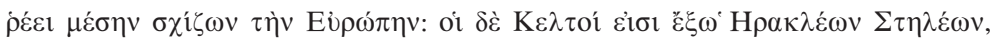

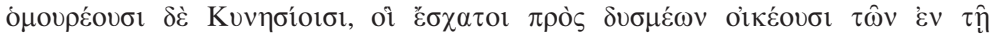

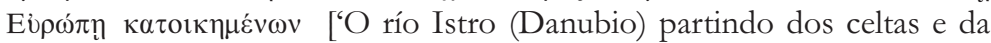
cidade de Pirene, corre polo centro de Europa e divídea. Os celtas están fóra das Columnas de Heracles e lindan cos cinesios, que por occidente son os últimos habitantes de Europa'].

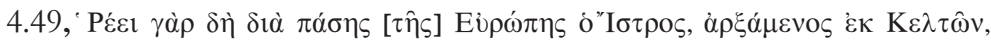

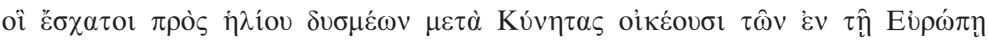
['O Istro recorre toda Europa partindo dos celtas, que, despois dos cinetas, son os últimos de Europa na súa parte occidental'].

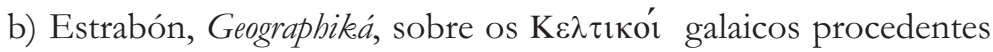
da Baeturia:

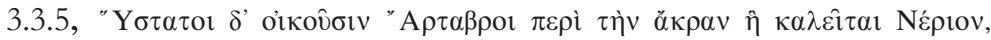

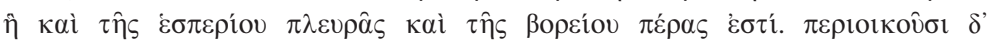

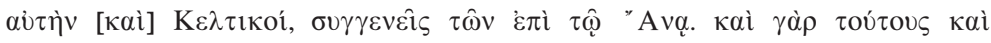

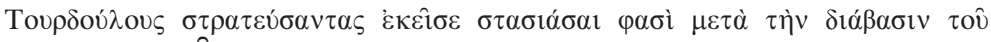

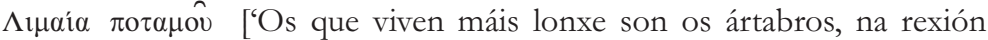
do cabo que chaman Nerio (Fisterra), que separa os flancos occidental e norte. Nela viven tamén célticos, emparentados cos da cunca do Anas (Guadiana). Din que nunha ocasión en que fixeron alí unha expedición estes xunto cos túrdulos, se sublevaron tras pasar o río Limia’].

c) Plinio, Naturalis Historia, 3.13 da orixe celtibera dos Celtici da Baeturia:

Quae autem regio a Baete ad fluvium Anam tendit extra praedicta, Baeturia appellatur, in duas divisa partes totidemque gentes: Celticos, qui Lusitaniam attingunt, Hispalensis conventus, Turdulos, qui Lusitaniam et Tarraconensem accolunt, iura Cordubam petunt. Celticos a Celtiberis [ex Lusitania] advenisse manifestum est sacris, lingua, oppidorum vocabulis, quae cognominibus in Baetica distinguntur ['A rexión que máis alá do que acabamos de describir vai do Betis ao río Anas chámase Beturia e divídese en dúas partes e outros tantos pobos: os célticos, que limitan con Lusitania, do convento hispalense, e os túrdulos, que forman fronteira con Lusitania e Tarraconense, pero dependen da xurisdición de Córdoba. 
Que os célticos chegaron dos celtiberos (desde Lusitania?) é manifesto nos ritos relixiosos, lingua e nome dos oppida, que na Bética se distinguen con sobrenomes'].

Pero estes movementos recentes, os documentados e outros a supor, non poden ser os responsables da indoeuropeización (case) total da onomástica de Gallaecia sen que o preindoeuropeo manteña unha pegada clara da súa preexistencia. Se Gallaecia e outras áreas hispánicas non son indoeuropeas orixinarias, a súa indoeuropeización ten que ser moi antiga, do Bronce Antigo ou mesmo do Neolítico. Neste carácter indoeuropeo pode ter algo que dicir a posición atlántica, en contacto activo con Bretaña e Illas Británicas, pero para non simplificarmos as cousas nun terreo tan propicio aos antollos haberá que recordar que a fachada cultural atlántica ten en tempo histórico e con raíz prehistórica unha notable diversidade lingüística, pois a celticidade de Hibernia, Britannia e Gallia e mais a celticidade ou, en todo caso, indoeuropeidade das áreas cantábricas e atlánticas de Hispania combínanse coa presenza non indoeuropea nas área de Aquitania e Vasconia, e tamén no Sudoeste hispánico, onde a documentación tartesia é non indoeuropea e o estrato céltico é recente ${ }^{18}$.

A indoeuropeidade de Gallaecia e Lusitania é parte da indoeuropeidade do conxunto hispánico non ibérico nin tartésico ${ }^{19}$, e para a considerar resultado da indoeuropeización dun espazo e dunha comunidade orixinariamente non indoeuropeos non hai, seica, no rexistro cultural arqueolóxico testemuñas dunha inmigración de xentes, transatlánticas ou continentais hispanas ou transpirenaicas, ás que facer responsables; pero esta sería a solución axiomática e por defecto, pois tampouco non se reconstrúen as condicións para que a nosa indoeuropeidade resulte dun proceso de difusión/asimilación lingüística desde centros de poder transatlánticos ou continentais hispanos ou transpirenaicos, e tampouco non parece que se poida falar dunha in-

${ }^{18}$ Pero o profesor sevillano Correa $(1992,1985)$ ten traballado na hipótese de que nas inscricións tartesias teñamos unha lingua céltica.

${ }^{19}$ Repito que non é o meu tema nin a miña capacidade de agora presentar as novas hipóteses de que poida remitirse a unha indoeuropeización moi antiga boa parte do material onomástico que se viña considerando tartesio ou ibérico, non indoeuropeo. Tamén hai hipóteses de que a lingua ibérica se estendese sobre un estrato preexistente celta ou celtoide. 
doeuropeización resultante da adopción dunha lingua franca ou koiné no tráfico comercial atlántico.

Somos, supoño, parte desde data moi antiga dun contínum indoeuropeo occidental no que vai caber variedade e abundancia de movementos étnicos e culturais, con ou sen as correspondentes consecuencias de expansión, extinción e mestura de linguas, así coma procesos de produción e expansión de isoglosas fónicas, gramaticais e léxicas desde os centros de poder e prestixio político e social das linguas dominantes, con consecuencias nos mapas dialectais. En todos estes procesos hai sempre simplificación do mapa lingüístico, que perde elementos ou os reduce a substrato ou a fósil onomástico.

\section{Celta, Celtibérico, galaico-Lusitano}

\subsection{Riscos non célticos}

A opinión tradicional e maioritaria nega o carácter céltico do material lingüístico galaico-lusitano e dá a este material un selo indoeuropeo occidental, pero tamén recoñece nese material elementos célticos que se consideran resultado de intrusións de poboación céltica desde outras áreas hispánicas (Celtiberia, Baeturia...) ou simplemente expansión das correspondentes isoglosas desde o seu centro de produción extragalaico-lusitano.

Ademais de argumentos no terreo onomástico que logo aludiremos e deixando de lado cousas que son problemáticas na súa documentación e/ou na súa discusión, entre os argumentos fono- e morfolóxicos máis destacados na negación do carácter céltico da lingua galaico-lusitana están:

a) A non eliminación de ide. ${ }^{*}$, que axiña discutiremos.

b) A presenza do fonema $f$, que as linguas célticas antigas descoñecen. Xa dixemos que a evolución *bh $>f$ en IFADEM (Cabeço das Fráguas) é certa, se previamente é acertada a etimoloxía proposta por Tovar ou a proposta por Prósper. O mellor será non insistir na discusión desta forma e non afirmar nin negar nada con base nela. Do material galaico-lusitano no que se pode rexistrar a evolución regular céltica das aspiradas sonoras indoeuropeas a sonoras xa dixemos que é 
seguro en parte; haino tamén máis ou menos probable, por exemplo, o teonímico EDOVIO (CIL II, 2543, Caldas PO) podería remitirse a ide. ${ }^{*} \mathrm{H}_{2} \mathrm{EIDH}$ - 'arder, lume'.

No caso de FINDENETICIS (CIL II 2471, Chaves, VR) e de FIDVENAE (CIL II, 5607, Paços de Ferreira, P) poderiamos ter o galaico-lusitano madrugando na evolución $* w>f$ que despois terá o irlandés medieval: o segmento FIND- poderíase remitir a celt. VINDO- 'branco' (cf. Vindobona, a actual Viena), e o segmento FIDV - a ide. *WIDHU- 'árbore, madeira' (cf. irl. fic). Para este par de formas tamén haberá que recordar o seu carácter illado e que a plausibilidade da etimoloxía non o mesmo que a súa confirmación. Hai outras formas, pero que non nos poden ocupar o tempo e que mesmo poden ter orixes que non son atranco ningún para a celticidade do material galaico-lusitano.

c) Uso da conxunción copulativa INDI (Cabeço das Fráguas GU; Arroyo de la Luz, CC), que as linguas célticas descoñecen. Esa conxunción ten as súas referencias comparativa claras nos actuais inglés and e alemán und.

\subsection{Indoeuropeo * ${ }^{*}>$ céltico común $\varnothing$}

$\mathrm{Na}$ definición tradicional, maioritaria, ortodoxa, do céltico común como póla da árbore indoeuropea dentro dos esquemas da Stammbaumtheorie ou 'teoría da árbore xenealóxica' que arrinca no s. XIX de Schleicher, é pedra angular a eliminación do fonema labial xordo * $p$ : por exemplo, no canto de lat. pater, gr. $\pi \alpha \tau n \rho$, ai. pitā, got. fadar... temos airl. athir < ide. ${ }^{*}{ }^{\mathrm{O}} \mathrm{HTE} \mathrm{R}$.

Esta innovación é anterior a que no grupo chamado Celta-P a casiña que deixa baleira a queda do ${ }^{*} p$ indoeuropeo teña o recheo, xa estable, do novo $p<$ ide. ${ }^{*} k^{w}$ e ${ }^{*} k w$. Na área - jnon grupo!- conservadora do Celta- $Q$ temos a conservación de ide. ${ }^{*} k^{w}$ e ${ }^{*} k w$, con posterior queda do seu elemento labial. Por exemplo, do numeral ide. ${ }^{*} \mathrm{~K}^{\mathbb{W}} \mathrm{ENK}^{\mathbb{W}} \mathrm{E}$ 'cinco' temos en Celta - $P$ o galés pimp, con $p$ estable, pero no Celta- $Q$ temos o gaélico coic con $c<* k^{w}$. Recórdese que todo o material hispánico é de Celta- $Q$, pois, por exemplo, de ide. ${ }^{*} \mathrm{EKWO}-$ 'cabalo', temos en Celta- $P$ o teónimo galo Epona, pero en Gallaecia temos o etnónimo Equaesi; a enclítica ide. ${ }^{*}{ }^{W \mathbb{E}} \mathrm{E}$ témola en lepóntico, Celta-P, como -pe, pero é -kue, -que en celtibérico. 
A queda do ide. ${ }^{*} p$ é segura na lingua celtibérica, por exemplo, en MLH K.3.18 VERAMOS pódese remitir a ide. *UPER- ${ }^{\circ}$ MOS e traducirse como un superlativo 'máis alto, supremo', pero nos textos lusitanos hai ide. * ${ }^{*}$ conservada, por exemplo en PORCOM (Lamas de Moledo e Cabeço das Fráguas), TREBOPALA (Cabeço), de interpretación funcional e etimolóxica moi discutida e a relacionar co epíteto TOUDOPALANDAIGAE en epígrafe latino de Talaván (CC), PETRANIOI (Lamas de Moledo).

Hai ademais onomástica transmitida por autores gregos e latinos e por epígrafes latinos, que se atopa tamén noutras áreas hispánicas e mesmo na Celtiberia e que tamén sorprende con $p$ que choca coa ortodoxia do Céltico Común, se é $p$ remisible a ide. ${ }^{*} p$, cousa que en máis dun caso é dubidosa ou mesmo moi incerta. Temos, por exemplo, o teónimo lucense POEMANA (IRPL 6), o epíteto teonímico lucense PARALIOMEGO (IRPL 5), o epíteto teonímico lucense PARAMAECO (IRPL 9), os etnónimos galaico PRAESRAMAR(I)CI, ástur PAESICI, celtibérico PELENDONES..., os hidrónimos PISORACA e actuais Pisorgo, Pisueña..., os antropónimos PENTIVS, PENTILVS, PINTAMVS, PINTLA... Aquí tamén poderían entrar, entre outros, os topónimos galegos actuais Partovia, Pambre (medieval Paambre, quizais de *PALAMBris) e Palas, a comparar cos comúns pala e paleira. O xa visto PARAMAECO complétase con in parami aequore da famosa ara votiva de Diana en León (CIL II 2660) e co común páramo, paramera e o seu rendemento toponímico; temos tamén Paraño(s) (material con $p$ en Untermann 1987: 69-74).

Todo este conxunto certo, probable ou dubidoso de ide. ${ }^{*} p$ conservada súmase a outros feitos cuxo valor diagnóstico, en si mesmo e na súa documentación, tamén é diverso e problemático (cf. 6.1.), para que a opinión tradicional e maioritaria conclúa que en Gallaecia e Lusitania temos un estrato indoeuropeo occidental non céltico que mesmo é presentado nalgún manual (por exemplo, Beekes 1995: 27) como póla autónoma da árbore indoeuropea. Por riba deste estrato temos un superestrato céltico que se estima procedente de Celtiberia, Baeturia... (cf. textos recollidos en 5.4) e que ten a súa peza máis emblemática nos topónimos con único ou con segundo elemento da raíz ide. * *BRgGH-, é dicir, BRIGANTIVM, ADROBRICA O ARDOBRIGA, AVOBRIGA, AVILIOBRIS... e os actuais Deixebre, Trobe, $O$ Grove...e quizais Briallo(s), de *BRIGALIUM (cf. o actual Trujillo $<$ Turgalium). 
Para estes topónimos quero sinalar que Arenas (2002: 22) e De Bernardo (2002: 106) teñen recoñecida a maior frecuencia de -briga, -brix e -bris en Gallaecia e Lusitania en comparación con outras áreas célticas hispánicas e coa particularidade de que -brix e -bris (actuais -bre, -ve) supoñen arcaísmo morfolóxico fronte a -briga Nestas condicións non é convincente ter por celtización con orixe na Celtiberia a abundancia galaico-lusitana destes topónimos, que máis ben resulta indicio dunha celtización realmente antiga ${ }^{20}$, pois ademais no excelente estudo que Rix (1954) dedicou aos topónimos do mundo céltico resulta que xa -briga 'altura', de Gallia e Hispania, parece o estrato máis antigo fronte a-dunum 'recinto' e -magus 'campo' 21 .

\subsection{Os textos lusitanos non son un 'castrapo'}

$\mathrm{Na}$ análise da documentación e no diagnóstico hai moitos factores en xogo e teño que me limitar a presentar brevemente un par deles.

En primeiro lugar direi que non é solución lóxica, senón mera petitio principii, a tese de que nos textos lusitanos teñamos un adianto do que hoxe chamamos castrapo, unha mestura de linguas lusitana e latina na

${ }^{20}$ Pero tamén hai que sinalar que: 1) A proliferación dun determinado tipo onomástico pode ir ligado a factores de moda e prestixio dos que no noso caso temos pouca ou ningunha noticia; no caso extremo mesmo podería suceder que un tipo toponímico frecuente nunha área non fose indicio válido da implantación nesa área da lingua á que pertence o dito tipo. 2) Pola articulación e densidade de núcleos de poboación que teñen Gallaecia e Lusitania é necesario que teñan maior abundancia de calquera tipo toponímico que compartan con Celtiberia e outras áreas hispánicas.

Non discuto aquí nin vexo documentada en Arenas (2002: 24) a súa hipótese de que a extensión dos -briga de documentación tardía nos dous terzos superiores da Península sexa un artificio dos reconquistadores, unha estratexia demagóxica para lexitimar os seus avances.

${ }^{21}$ Rix dividiu o mundo céltico en tres áreas: 1) topónimos con segundo elemento -dunum (Lugudunum, Camulodunum) en Gallia, Britannia, algún exemplo en Hibernia, e extensión polo val do Danubio; 2) topónimos con segundo elemento -magus (Maromagus, Rotomagus) en Gallia, Britannia, Hibernia; 3) topónimos con segundo elemento -briga (Nemetobriga, Segobriga) en Gallia e Hispania. Para o valor diagnóstico de -briga na indoeuropeización de Hispania véxase Untermann (1961). Destes tres elementos e da súa repartición xa fixera unha colleita e interpretación boa (para o seu tempo) Buchanan ao tratar da linguae inter Gallos et Britannos communionem en Rerum Scoticarum Historia (1582). 
que as formas polémicas, por exemplo, PORCOM, deixan de ser polémicas porque as consideramos intrusións latinas que suplantan a forma lusitana xenuína do mesmo xeito que, poño por caso, no castrapo o conexo, a escoba... están onde tiñan que estar o galego coe(n)llo, vasoira...

Esta tese podería amañar algo nos textos de Lamas de Moledo e Cabeço das Fráguas, pero non podería facer nada nos textos de Arroyo de la Luz (cf. 1.1.) nin na moita onomástica indíxena que nada ten que ver co castrapo e que trae problemas de encaixe da lingua galaico-lusitana no grupo céltico e no conxunto indoeuropeo.

E tampouco non é de recibo sospeitar erro do lapicida onde convén e acadamos unha lectura máis cómoda. Por exemplo, o discutido ANGOM de Lamas de Moledo pódese corrixir en *agnom e así teríamos un año que nos encaixa moi ben co PORGOM de máis abaixo e tamén coa aparente suovetaurilia que temos en Cabeço das Fráguas.

\subsection{Innovación e conservación na taxonomia de linguas}

O punto principal de discusión está en que, como xa ficou implícito máis atrás, a comparación e a reconstrución con que a escola neogramática ou Junggrammatiker dá madureza á lingüística indoeuropea é tallante en lle non atribuír valor diagnóstico á conservación dun estado de cousas, pero si á innovación e mais á elección para establecer grupos, fronteiras e etiquetas no mapa de linguas e dialectos.

En teoría e práctica tradicionais e maioritarias a innovación ide. ${ }^{*} p$ $>\varnothing$ é decisiva para definir o céltico común intermedio entre a protolingua indoeuropea e as linguas celtas históricas. A conservación de ide. * ${ }^{*}$ deixa a lingua galaico-lusitana fóra dese céltico común no que si entran as linguas celtibérica, gala e lepóntica na área continental e con documentación antiga, e as linguas gaélica, manx e escocesa, galesa, córnica e bretoa na área insular e con documentación medieval ${ }^{22}$.

A aplicación rigorosa deste criterio parece correcta pois, por exemplo, non sería do fondo léxico que a lingua grega recibe da súa

\footnotetext{
22 A lingua bretoa, da Bretaña francesa, ten orixe británica: é dos celtas que foxen da presión anglosaxona. Para as linguas célticas insulares hai documentación antiga, pero reducida á onomástica que coñecemos por textos gregos e por textos e epígrafes latinos.
} 
orixe indoeuropea unha palabra que non eliminase o fonema $s$, con resultado $h$ - ou $\varnothing$ - (psilose), no contexto $*_{s} V$ : por exemplo, ide. *S(W)EKS, *SEPTM, *SEK ${ }^{W}$ - serán sex, septem, sequor en latín, pero $\check{c}^{*} \xi$,

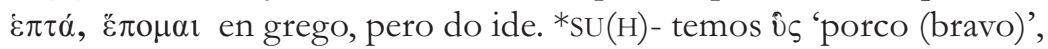
xenuinamente grego, mentres $\sigma \hat{\varsigma} \varsigma$ é grego tamén, pero hai que o ter por préstamo doutra lingua indoeuropea na que ${ }^{*} V$ - era estable.

Tamén por aplicación rigorosa deste criterio non pode ser patrimonial latina a palabra na que rexistremos a innovación ide. ${ }^{*} k^{w}>p$, pois é descoñecida do latín, que conserva o fonema labiovelar xordo e grafía qu (cf. quis, quando, quattuor, linquo, sequor...); así, ide. ${ }^{*} \mathrm{LUK}^{\mathrm{W}} \mathrm{OS}>$ lupus é un préstamo dos veciños oscos e umbros, que si coñecen a innovación ide. ${ }^{*} k^{w}>p$.

Pero a aplicación rigorosa tamén pode levar a paradoxos e salsepodes. Por exemplo, con base na gheada, no ceceo, no seseo... nos sistemas da lingua galega e da española teriamos innovacións e casiñas baleiras con rango fonolóxico abondo para negar a galeguidade ${ }^{23}$ ou a españolidade de determinadas áreas de ambos os idiomas e o máis sorprendente sería que coa implantación que hoxe ten o seseo o idioma español actual ficaría reducido a catro gatos, se a distinción entre coser e cocer, casar e cazar... actuase como decisoria, pois coser e casar son o único que fala unha amplísima maioría, que mesmo tería dereito a decretar que non falan español os que están no que foi berce e aspersor da lingua.

Parece que un só feito fonolóxico, por importante e aparente que sexa, non é abondo para afirmar ou negar a inclusión dunha lingua nun determinado grupo. Hai outros feitos a considerar, pero tamén hai que considerar, con Scherer (1954), que o decisivo na conformación e diferenciación das linguas que pertencen a un tronco común -e, polo tanto, o traballo do taxonomista- non está tanto no sistema fónico e nas súas incidencias como no terreo gramatical e léxico, no terreo dos que son signos, no que é materia necesaria e pertinente na comunicación.

\footnotetext{
${ }^{23}$ A grande maioría dos galegos teñen gheada, pero a presión do castelán deitou unha
} norma culta urbana que ten por paifocos os que din ghato, Lugho... 


\section{5. ¿É celta unba lingua que mantén ide. * ${ }^{*}$ ?}

É maioritaria a opinión -García Alonso (2003), Gorrochategui (1987 e 1997), Mc Cone (1996), De Hoz (1993), Michelena (1976), Prósper (2002), K. H. Schmidt (1985 e 1992), Schmoll (1959), Tovar (1967, 1968, 1983, 1985, 1986, 1987), Villar (1990a, 1990b, 1994, 1996a, 2004)...- de que a conservación de ide. ${ }^{*} p$ é proba da non celti(ci)dade da lingua galaico-lusitana, pero, despois de revisar o material con / $p /$ na Hispania indoeuropeizada -material case todo onomástico e que, moi importante, tamén se rexistra na Celtiberia e áreas próximas ${ }^{24}$ Untermann (1987: 74) avisa «Ich fürchte, eines Tages werden die Keltisten lernen müssen, mit dem $p$ zu leben», é dicir, «Témome que algún día os celtólogos van ter que aprender a convivir co p». Tamén Búa (1997: 73) insiste na insuficiencia de que a conservación de ide. * ${ }^{*}$ exclúa a celti(ci)dade da lingua galaico-lusitana. Na longa e minuciosa revisión que De Bernardo (2002) fai do celta peninsular hispano non vexo que a conservación de ${ }^{*} p$ se teña en conta para negar a celti(ci)dade da documentación galaica e lusitana. E hai outras voces autorizadas, por exemplo, a de Evans (1993: 597), «hardened Celtologists, and others, have by and large failed to emerge altogether unscathed (myself among them) from contemplation (whether it be fleeting or intense) of the awkward questiones occasioned by the mesmeric $p$ of this particular range of forms» (quere dicir, paramus, Palantia, Poemana, porcom...), pero coa conclusión (1989: 598) de que «for me it is neither a failure to resist temptation nor a view based on firm conviction to dally with the thought that the vaguely delimited Lusitanian is in some ways potentially, even perhaps markedly, Celtic despite all the trouble still caused by some confounding forms and patterns».

O tempo dirá se non se traballou nun estereotipo do céltico no que os criterios excesivamente estritos de taxonomía lingüística xuntáronse co condicionamento tamén excesivo de criterios extralingüísticos que contribuían a facer da celti(ci)dade do mundo galorromano e medieval das Illas Británicas o canon único. Ademais de abrir a celti(ci)dade étnica e cultural á riqueza sincrónica e diacrónica que realmente ten e

\footnotetext{
${ }^{24}$ Pero recórdese que a certeza de que o $p$ documentado se remita a ide. ${ }^{*} p$ non é a mesma en todos os casos e hai inseguridade en bastantes deles.
} 
ademais de separar debidamente os datos étnicos e culturais dos datos lingüísticos, cumprirá unha renovación dos criterios lingüísticos que dea xogo ao relevo documental que hoxe ten a Hispania indoeuropea e se cadra iremos dar no recoñecemento dun celta marxinal e conservador, un celta con ide. ${ }^{*} p$ mantido.

\subsection{A isoglosa ${ }^{*} p>\varnothing$}

O máis relevante na discusión do mantemento ou da queda do ide. ${ }^{*} p$ é que é clara a dita queda na documentación celtibérica, dunha área que en tempo histórico perdeu contacto co conxunto de linguas célticas continentais e insulares nas que tamén se rexistra esa mesma queda. Non se exclúe, pero non parece fácil, que a lingua celtibérica prehistórica fixese esa innovación con independencia desoutras áreas célticas. Haberá que optar, xa que logo, por:

a) A lingua celtibérica e as célticas ultrapirenaicas foron en tempo prehistórico un contínum que quebrou pola intrusión de xentes que falaban linguas do ámbito aquitano, ibérico, vascón ${ }^{25}$; nesta opción habería que revisar se hai ou non hai algunha mostra certa de substrato indoeuropeo (céltico ou non) na área nordeste de Hispania que historicamente é de lingua ibérica ${ }^{26}$.

b) A lingua celtibérica ten orixes prehistóricas ultrapirenaicas e chegará a ser celtibérica por movemento dos seus falantes, que se superpoñen a poboación non indoeuropea, ibérica (¿e vascona?), e tamén a

${ }^{25}$ Aquí habería que deitar medio folio sobre o problema mito/antollo da antigüidade mesmo paleolítica dos vascos na súa terra e resistentes a celtiberos, romanos, visigodos, árabes... Co argumento da onomástica antiga e con outros datos lingüísticos e non lingüísticos pode ser certo que o de Provincias Vascongadas significa unha vasconización ou eusquerización desas áreas en tempo xa tardoantigo e altomedieval e con orixe na Aquitania (actual País Vasco francés) e na Navarra e áreas pirenaicas do actual Aragón (cf. Untermann 1983: 811).

Nesta perspectiva de que os recentes sexan os iberos tamén podería ser revisada a posición crítica actual ante os Campos de Urnas como pegada do movemento de indoeuropeización/celtización da Península, pois a ocupación ibérica da área nordeste onde se rexistran eses Campos sería posterior, desprazaría o elemento indoeuropeo e sería causante de que nela a documentación lingüística sexa ibérica.

${ }^{26}$ Esas revisións xa están en marcha, pero non nos poden ocupar. Ademais recórdese o dito na nota 11. 
poboación indoeuropea occidental á que non chegou a isoglosa ide. ${ }^{*} p>\varnothing$, pero que é céltica noutros moi importantes puntos de lingua e, inda que non sexa o noso tema nin o noso interese, tamén noutros campos da cultura material e espiritual.

Postos nesta opción, habería que ver se elevamos a conclusión definitiva a hipótese que presenta Untermann (1992b: 32) sobre os etnónimos da área noroeste -Gallaecia e Asturica-, plenamente integrados no repertorio antropo- e toponímico da Hispania céltica, en contraste coas áreas centrais, en especial a lusitana e a celtibérica, que presentan etnónimos desligados do restante repertorio antropo- e toponímico e que, polo tanto, poderían deberse ao substrato lingüístico que foi marxinado pola intrusión dos falantes da lingua céltica.

Nesta discusión da orixe e extensión da queda do ide. * ${ }^{*}$ Gallaecia e Lusitania perden a súa conexión atlántica, tan suxerinte noutros aspectos, pois os celtas atlánticos -británico e goidélico- eliminaron ide. ${ }^{*} p$. Se hai algún caso certo de queda de ${ }^{*} p$ no material galaico que logo imos citar e outro que cumpriría buscar, haberá que pensar en movementos de poboación desde Celtiberia e Lusitania, por exemplo os que xa vimos citados en Estrabón e Plinio, ou pensar tamén na alternativa de difusións culturais que leven aparellada a difusión de palabras con $\varnothing<{ }^{*} p$.

\section{7. $\dot{2}^{*}>\varnothing$ en Gallaecia?}

En Gallaecia/Galicia temos algún exemplo seguro ou probable de queda de ${ }^{*}$, por exemplo no actual (Ponte) Ledesma, a comparar con CIL II 858 e 859 Bletis(amam), hoxe Ledesma, de territorio vetón, que é o superlativo ${ }^{*} \mathrm{PL}_{\mathrm{PLH}} \mathrm{T}_{1} \mathrm{~T}-\mathrm{IS}^{\mathrm{O}} \mathrm{MA}$, 'moi ampla'. Temos o castellum en ablativo Blaniobren $[$ s $7 \mathrm{i} \mathrm{de}$ CIL II 2902 (Astorga LE), a situar en área dos Célticos Supertamáricos e que podería ser o Lañobre hoxe perdido (Arteixo C) (Búa 1997: 64). Quizais A Olga (Pastoriza LU) podería compararse co galolatino olca, francés ouche, castelán buelga, Las Huelgas... de ide. *POLKA 'campo de labranza, horta'. Os topónimos Osmo (Cenlle OU), Lamas de Brosmos e Portabrosmos (Sober LU), Beresmo, medieval Verosma (Avión OU) poderíanse comparar coas Uxama celtibéricas, hoxe Osma, de *UPS- ${ }^{\circ} \mathrm{MA}$ 'moi alta', e -br-e Ver-, Ber-Br-poderíanse remitir a *UPER-, cf. o celtibérico xa visto VERAMOS 'supremo', galo uer- en antropónimos como Vercingetorix, Vercobius... 


\subsection{Algúns elementos da celti(ci)dade de Gallaecia e Lusitania}

1. Na valoración da presenza de celtas na Gallaecia hai que dicir

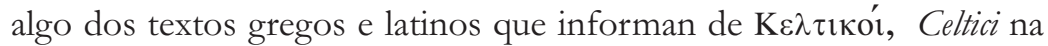
Gallaecia. Repito o texto de Estrabón, Geographiká, 3.3.5 sobre os célticos galaicos procedentes da Baeturia:

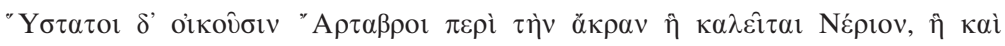

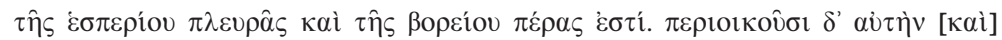

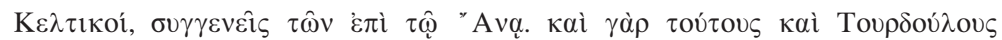

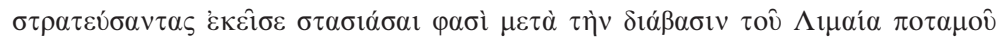
['Os que viven máis lonxe son os ártabros, na rexión do cabo que chaman Nerio (Fisterra), que separa os flancos occidental e norte. Nela viven tamén célticos, emparentados cos da cunca do Anas (Guadiana). Din que nunha ocasión en que fixeron alí unha expedición estes xunto cos túrdulos, se sublevaron tras pasar o río Limia'].

E quero engadir unha referencia á conclusión de Untermann (2004b: 483) sobre o selo lingüístico celta dos Turduli ueteres que fixeron

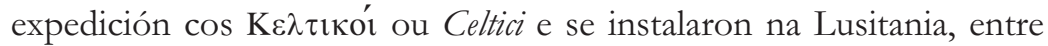
Douro e Mondego. Temos ademais,

Mela, Chorographia 3.10-12

Ad promunturium quod Celticum vocamus extenditur. totam Celtici colunt, sed a Durio ad flexum Grovi, fluuntque per eos Avo, Celadus, Nebis, Minius et cui oblivionis cognomen est Limia ['Esténdese (a costa) ata o promontorio que chamamos Céltico (Fisterra). Habítana toda ela célticos, pero desde o Douro ata a curvatura grovios, e polas súas terras corren Ave, Celado, Nebis, Miño e Limia, co sobrenome do Esquecemento'].

\section{Plinio, Naturalis Historia}

3. 28, Lucensis conventus populorum est sedecim, praeter Celticos et Lemavos ignobilium ac barbarae appellationis, sed liberorum capitum ferme CLXVI. Simili modo Bracarum XXIIII civitates CCLXXXV capitum, ex quibus praeter ipsos Bracaros $<\mathrm{B}>$ ibali, Coelerni Callaeci, $<\mathrm{E}>$ quaesi, $\mathrm{Li}<\mathrm{mi}>\mathrm{ci}$, Querquerni citra fastidium nominentur ['O convento lucense ten dezaseis pobos, descoñecidos e de nome bárbaro agás célticos e lémavos. Así mesmo o dos brácaros <ten> vinte e catro cidades e douscentos oitenta e cinco mil homes, e deles citaremos, sen chegarmos ao fastío, ademais dos brácaros, os bíbalos, celernos calaicos, ecuesos, límicos, cuercuernos']. 
4.111-112, Conventus Lucensis a flumine Navia Albiones, Cibarci, Egi, Varri cognomine Namarini, Adovi, Arroni, Arrotrebae. promunturium Celticum, amnes Florius, Nelo. Celtici cognomine Neri et super Tamarci, quorum in paeninsula tres arae Sestianae Augusto dicatae, Copori, oppidum Noeta, Celtici cognomine Praestamarci, Cileni. ex insulis nominandae Corticata et Aunios. a Cilenis conventus Bracarum Helleni, Grovi, castellum Tyde, Graecorum subolis omnia ['O convento lucense a partir do río Navia, cos albiones, cibarcos, egos, varros (?) chamados namarinos, adovos, arrones e arrotrebas. O promontorio Céltico, os ríos Florio e Nelo; célticos chamados nerios e supertamarcos (?), en cuxa península se dedicaron a Augusto as tres aras sestianas; os cóporos, o oppidum Noeta (?), os célticos denominados praestamarcos, cilenos. Das illas merecen mención Corticata e Aunio (Ons). Desde os cilenos o convento dos brácaros, helenos, grovios e o castellum Tyde (Tui), todos da liñaxe dos gregos'].

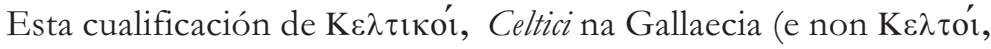
Celtae), creo que non significa algo así como un rebaixado semellantes aos celtas polo peso que tiñan os estereotipos celtas baseados nos

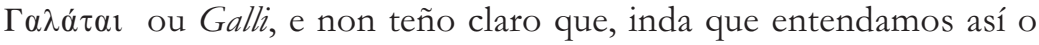
nome, a súa aplicación puntual a uns galaicos exclúa a celticidade dos outros, polo menos a celticidade lingüística, se temos en conta que a repartición do material onomástico céltico indoeuropeo de todo tipo por toda a Gallaecia é clara, ademais de non termos moi claro en que medida Estrabón, Mela, Plinio, etc. fixeron da lingua un criterio

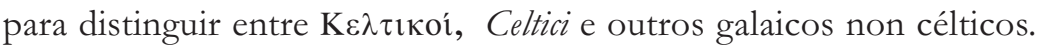

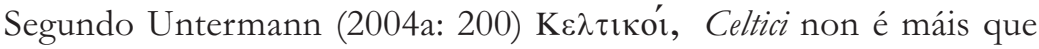
o nome das de unidades tribais (celtas) que da meseta migraron cara ao SO e do SO cara ao NO, tal como informan os textos arriba $\operatorname{citados}^{27}$.

2. Insisto na abundancia de hidrónimos que encaixan ou parecen encaixables no Alteuropäisch definido por Krahe ou teñen xa características específicas do céltico: Ambia, Avia e Avión, Ézaro (¿*Aisaros?), med. Ez̧a (¿*Aisa?), Aranza, med. Alesantia, Aliste > Este, med. Alesgos

\footnotetext{
${ }^{27}$ Véxase en Untermann (2004a: 200) a súa oposición á opinión de De Hoz (1993 e

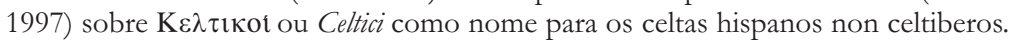
A posición de Untermann (2004a) xa está prefigurada en Untermann (2001). Máis sobre Celtici e Turduli en Untermann (2004b).

Pero o traballo de De Hoz (1997) é bo para vermos os criterios de etnicidade que puideron ser operativos en como nos viron os romanos.
} 
$>$ Esgos, Barbanza, Camba, o repetido Condado para confluencias, o repetido Deva, Dubra, Homem e varios O Mao que son reinterpretación do med. Humano, Iso, Limia, Minius > Miño, Navea, Navia, Neira, Narla, Sars $>$ Sar, Tamaris/Tamara > Tambre, Támega, Tamoga, Tamuxe, Umia, med. Vernesga...

Xa falamos na abundancia de topónimos antigos en -briga, -bris e as continuacións actuais en -bra, -bre e -be ou -ve (nestes dous últimos casos por metátese, med. Talobre $>$ Trobe; ou por disimilación de $r$, ${ }^{*}$ CASTROBRE > Castrove; por disimilación e metátese en *OKROBRIS $>$ med. Ocobre $>O$ Grove). Ademais da toponimia rexistrada en data antiga, na actual hai moreas de material medieval e actual que agardan recollida e sistematización, por exemplo, os tipos med. Auania $>A$ Baña, Bendaña, Cervaña... ou Baroña, Carantoña, Visantoña... ou Coroño, Ledoño, Londoño... ou Laraño, Lantaño... ou Caranza, Arganzo, Camanzo, Miranzo, Vimianzo... Pero mellor que deitar exemplos será sinalar o moito e moi interesante que queda por facer na recollida sistemática de materiais, con inventario de raíces e sufixos e coas referencias comparativas que sexan oportunas. Por exemplo,

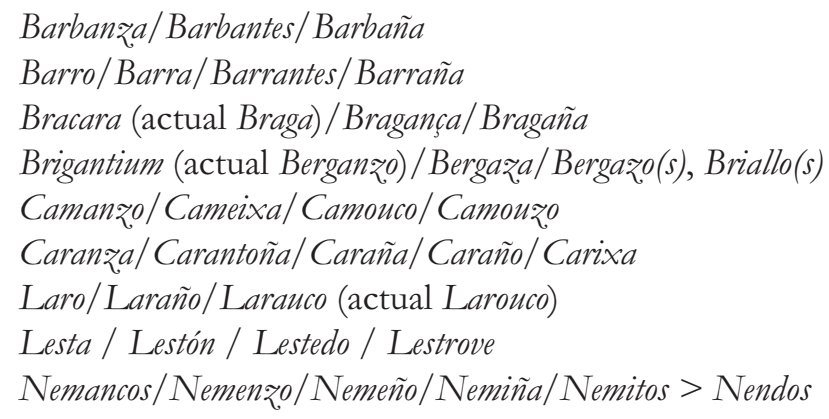

Tamén hai que recordar que os abundantes Bouza(s), Bouca(s), Varcia, Várzea, Barxa(s), Barja(s), Gándara(s), Granda(s), Lama(s) e moitos máis son de filiación problemática e quizais necesiten un estudo que deixe atrás moitas inercias, en especial o recurso a migracións e estratos varios e previos á indoeuropeización e máis ao céltico.

3. Gallaecia e Lusitania rexistran unha antroponimia que en bastantes dos nomes, tanto simples coma compostos, parecen de celti(ci)dade clara ou, en todo caso, son indoeuropeos - Alluquius, Ambatus, Balaesus, Bedunus, Camalus, Cloutius, Clutamus... Esta antroponimia articúlase nun 
contínum hispano que para Untermann non ten límites tallantes que nos poñan ante linguas diferentes, senón transicións graduais típicas da unidade de lingua con variacións dialectais. Non quero agachar que nesta antroponimia hai pezas de celti(ci)dade polémica, por exemplo, Parraq(um), Pangenda, Pentius, Pintavius, Pintamus... con $p$ - mantida.

Ademais tamén hai que recordar que unha área onomástica, Namengebiet, non é sen máis sinónimo dunha área lingüística, Sprachgebiet, porque a antroponimia é terreo propicio para modas e tendencias varias. Pero tamén pode ser certo que a comunidade nas modas e tendencias presupoña comunidade lingüística. En calquera caso e fronte do valor de prospección (pre)histórica que poden ter hidro- e toponimia, a antroponimia non é válida na reconstrución das nosas orixes, pois reduce o seu valor informativo ao momento en que viven as persoas portadoras dos nomes en cuestión ${ }^{28}$.

4. Os paleohispanistas teñen a liña Oviedo-Mérida para sinalar diferenzas relevantes: á esquerda desa liña o individuo identifícase co seu nome e o seu patronímico e, ao $\mathrm{N}$ do Limia, coa súa adscrición a un castellum $-\mathrm{O} \supset$ ou C invertido- (cf. CIRG I, 52, CAELEO CADROIOLONIS $F(I L I U S) \supset B E R I S A M O)$, mentres á dereita desa liña o individuo identifícase coa mención da familia en xenitivo de plural, por exemplo en $M L H$ IV K.0.2 lubos.alidokum.analo.ke(ntis) kontebiađ belaiskad, é dicir, Lu(b)bo, dos alisocos, fillo de Avalo, de Contrebia Belaisca; ou na Tabula Contrebiensis, texto latino, Segilus Annicum Lubbi f., é dicir, Segilo, dos Annicos, fillo de Lubbo.

Ademais, soamente á esquerda desa liña Oviedo-Mérida temos rexistro dos teónimos BANDVE, COSSVE, NABLAE, MVNIDI, REVE e TONGOE (coas súas variantes formais), mentres que doutros teónimos hai rexistro nos dous lados da liña, por exemplo, os $L V G V B O$ e $L V C O V B V$ lucenses compleméntanse cos LVGOVIBVS e LVGVEI na Celtiberia.

Estas diferenzas e outras son certamente importantes, pero son de orde cultural; teñen reflexo necesario na documentación, pero non son diferenzas lingüísticas nin, en tanto que diferenzas culturais, obrigan a

\footnotetext{
${ }^{28}$ E por todas estas e outras consideracións e tendo presente a nosa experiencia (nomes latinos, gregos, bíblicos, xermánicos...) tampouco non ten valor diagnóstico que na Hispania indoeuropea poida haber nomes non indoeuropeos, que sería simple asignar a un substrato preindoeuropeo, se non hai boa base documental para tal cousa.
} 
supor que tamén as hai lingüísticas. Nótese que o mundo lingüístico céltico ten de sempre unha notable variedade cultural no espazo e no tempo, ademais de que non haxa nas cerámicas, nas armas e alfaias, na habitación e nos enterramentos, na organización social, na relixión, etc. previsión algunha de qué lingua ou dialecto teñen as xentes en cuestión.

\section{CONCLUSIÓNS}

Se nun repaso tan sumario de catro cousas e con silencio de catrocentas podemos chegar a conclusións, ímolas adiantar, pero sen deixar o ton de hipótese e reserva con que quixen proceder en todo momento.

1. O argumento onomástico, en especial a hidronimia, suxíreme que desde data moi antiga é indoeuropea toda ou a maior parte da Hispania que chamamos indoeuropeizada.

2. A indoeuropeización podería mesmo ceder paso a un carácter indoeuropeo orixinario, ben entendido que falamos nos límites da nosa capacidade reconstrutiva dunha lingua. A escaseza e/ou pouca consistencia do substrato preindoeuropeo invita a esa opción, mais abondará con sermos indoeuropeizados en data moi antiga con dous posibles frontes, o consabido transpirenaico centroeuropeo e mais o atlántico. Pero non hai, seica, ningún rexistro arqueolóxico de movementos de poboación ou de difusións/captacións culturais que parezan suficientes para proceso tan importante como é o da nosa indoeuropeización.

3. Movémonos nun indoeuropeo occidental no que, ademais da perda axiomática de moita documentación e mesmo linguas enteiras, historicamente callan os grupos xermánico, itálico e céltico.

O material galaico-lusitano, común e onomástico, pode terse por céltico, inda que non participe nalgunha elección e innovación importante e non encaixe no canon tradicional (galo + celta insular medieval) que, por certo, tampouco non é acatado a tope polas novidades celtibéricas cuxa celtidade ninguén pon en dúbida.

4. Dentro da mobilidade axiomática de xentes e linguas, Gallaecia e Lusitania mostran influxos da Celtiberia e doutras áreas, pero non parece que estea aí o factor primeiro ou principal da nosa indoeuropeización/celtización. 